\title{
Geochemistry of fluids discharged from mud volcanoes in SE Caspian Sea (Gorgan Plain, Iran)
}

\author{
Mahin Farhadian Babadi, Behzad Mehrabi, Franco Tassi, Jacopo Cabassi, \\ Elena Pecchioni, Ata Shakeri \& Orlando Vaselli
}

To cite this article: Mahin Farhadian Babadi, Behzad Mehrabi, Franco Tassi, Jacopo Cabassi, Elena Pecchioni, Ata Shakeri \& Orlando Vaselli (2020): Geochemistry of fluids discharged from mud volcanoes in SE Caspian Sea (Gorgan Plain, Iran), International Geology Review, DOI: $10.1080 / 00206814.2020 .1716400$

To link to this article: https://doi.org/10.1080/00206814.2020.1716400

View supplementary material $[7$

Published online: 27 Jan 2020.

Submit your article to this journal $\pi$

Q View related articles ¿

View Crossmark data $־$ 


\title{
Geochemistry of fluids discharged from mud volcanoes in SE Caspian Sea (Gorgan Plain, Iran)
}

\author{
Mahin Farhadian Babadi ${ }^{\mathrm{a}}$, Behzad Mehrabi ${ }^{\mathrm{a}}$, Franco Tassi ${ }^{\mathrm{b}, \mathrm{c}}$, Jacopo Cabassi $\mathbb{D D}^{\mathrm{c}, \mathrm{b}}$, Elena Pecchioni $\mathbb{D}^{\mathrm{b}}$, \\ Ata Shakeri $\left(\mathbb{D}^{\mathrm{a}}\right.$ and Orlando Vaselli ${ }^{\mathrm{b}, \mathrm{c}}$

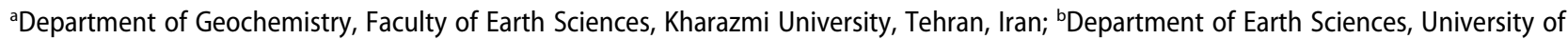 \\ Florence, Florence, Italy; 'CNR-IGG Institute of Geosciences \& Earth Resources, Florence, Italy
}

\section{ABSTRACT}

A geochemical study was carried out on gas, water and mud samples from four mud volcanoes in Gorgan Plain, SE Caspian Sea (Iran) in order to investigate fluid primary sources and secondary processes controlling fluid chemistry. The chemical composition of light alkanes and the isotopic feature of methane indicated an origin related to a thermogenic source. Gases discharged from Neftlijeh evidenced anaerobic biodegradation processes with addition of secondary microbial methane. Chemical composition of discharged waters revealed two main groups i) brine-type $\mathrm{Na}^{+}-\mathrm{Cl}^{-}$waters from Gharenyaregh and Neftlijeh mud volcanoes, which were marked by relatively high $\mathrm{Na}^{+} / \mathrm{Cl}^{-}, \mathrm{B} / \mathrm{Cl}^{-}$and $\mathrm{Li} / \mathrm{Cl}^{-}$ratios and low $\mathrm{Ca}^{2+} / \mathrm{Cl}^{-}, \mathrm{Mg}^{2+} / \mathrm{Cl}^{-}$and $\mathrm{K}^{+} / \mathrm{Cl}^{-}$ratios, ii) waters from Sofikam and Inche, characterized by relatively low $\mathrm{Na}^{+} / \mathrm{Cl}^{-}, \mathrm{B} / \mathrm{Cl}^{-}$and $\mathrm{Li}^{-} \mathrm{Cl}^{-}$ratios and relatively high $\mathrm{Ca}^{2+} / \mathrm{Cl}^{-}, \mathrm{Mg}^{2+} / \mathrm{Cl}^{-}$and $\mathrm{K}^{+} / \mathrm{Cl}^{-}$ratios. The chemical and isotopic characteristics of the discharged waters suggest that evaporated Caspian seawater trapped in sediments is likely representing a reliable water source. The maximum formation depth at Gharenyaregh and Neftlijeh mud volcanoes were estimated at about $6 \mathrm{~km}$ depth whereas the generation depth of the rest was significantly shallower. Thus, the observed compositional differences can be related to the different depths of the fluid source feeding them.

\section{ARTICLE HISTORY}

Received 3 September 2019

Accepted 12 January 2020

\section{KEYWORDS}

Mud volcanoes; fluid geochemistry; secondary geochemical processes; Gorgan Plain; Caspian Sea; Iran

\section{Introduction}

Mud volcanoes (MVs) are produced by the outflow of mud, water and gas phases, mostly consisting of methane, with significant concentrations of higher hydrocarbons compounds, $\mathrm{CO}_{2}, \mathrm{~N}_{2}$ and $\mathrm{H}_{2} \mathrm{~S}$, released by overpressured organic-rich sediments rapidly buried in sedimentary basins (Dia et al. 1999; Milkov 2000; Dimitrov 2002; Etiope et al. 2007). Fluids uprising through deep-rooted feeding channels may also be stored in mud chambers located at intermediate-toshallow depth, giving rise to buried MVs that can be recognized with geophysical surveys (Deville et al. 2003; Mazzini et al. 2009). MVs occur in many sedimentary basins related to convergent plate margins, accretionary wedges, passive margins within deltaic systems (Kopf et al. 2001), and active hydrothermal areas (Etiope et al. 2002). They are known to be associated with faults and faulted anticlines in active tectonic settings (Kopf 2002), where the tectonic stress, mainly compressional, acts as the main driving force. MVs are investigated for hydrocarbon exploration, as a possible evidence of subsurface petroleum accumulations (Deville et al. 2003;
Milkov 2005; Etiope et al. 2009a), and pose environmental concerns, since methane is a potent greenhouse gas (Milkov 2005; Etiope et al. 2008).

The origin of methane and light hydrocarbons discharged from MVs is commonly ascribed to (i) thermal degradation of pre-existing organic material (thermogenesis) and/or (ii) microbial activity (Bernard et al. 1978; Schoell 1980, 1983; Chung et al. 1988; Seewald et al. 1998; Whiticar 1999; Seewald 2003; Takai et al. 2008), the latter not being necessary related to any potential source rock (Schoell 1983). Gases from these two sources can be distinguished by using the carbon isotopic composition of methane (Milkov and Etiope 2018): $\delta{ }^{13} C_{1}$ values lighter than $-50 \%$ vs. V-PDB are typical of microbial activity, i.e. a process proceeding through either fermentation or carbon dioxide reduction, whereas $\delta^{13} C_{1}$ values from $-15 \%$ o to $-75 \%$ vs. V-PDB are commonly shown by thermogenic methane, i.e. thermal breakdown of pre-existing organic matter, typically associated with relatively high concentrations of heavier hydrocarbons (Whiticar 1994). Carbon and hydrogen isotopes of methane coupled with the relative abundances of light alkanes are used to discriminate

CONTACT Mahin Farhadian Babadi mahin.farhadian@gmail.com D Department of Geochemistry, Faculty of Earth Sciences, Kharazmi University, Tehran, Iran (4) Supplemental data for this article can be accessed here. 
between these two-genetic processes (Bernard et al. 1978; Schoell 1980, 1983; Chung et al. 1988; Whiticar 1999), since thermogenic gases have relatively high concentrations of ethane, propane, butane and pentane than those recorded in microbial gases (Schoell 1980; Hinrichs et al. 2006). However, the original chemical and isotopic composition of deep-originated gas may be affected by post-genetic processes, such as anaerobic biodegradation of petroleum coupled with an addition of secondary microbial methane occurring at relatively shallow depth (Pallasser 2000; Etiope et al. 2009b; Milkov 2011, 2018), which may mask the pristine chemical and isotopic features of the primary gases.

Consequently, $C_{1}-C_{4}$ hydrocarbons were widely investigated to reveal the origin of gas discharged from fluid escape in sedimentary structures associated with various geologic settings (e.g. Delisle et al. 2002; Deville et al. 2003; You et al. 2004; Guliyev et al. 2004; Etiope et al. 2006, 2007; Tassi et al. 2012; Prinzhofer and Deville 2013; Ray et al. 2013). A data-set including chemical and isotopic signatures of light hydrocarbons discharged from worldwide onshore MVs indicated that they are dominantly related to thermogenic process (Etiope et al. 2008, 2009a), suggesting the presence of a potential source rock at catagenetic stage, i.e. occurring at temperatures typically $>60^{\circ} \mathrm{C}$ (Hunt 1984; Milkov 2005). Chemical and isotopic compositions of the water phase discharged from MVs are good tracer to identify type and possible source of fluid. Additionally, useful insights can be obtained on depositional environments (presence of marine or non-marine evaporites), diagenetic processes, such as dissolution and precipitation of minerals, ion exchanges, organic matter degradation and clay mineral dehydration, which can be affected by temperature, depth and mixing processes (Rittenhouse 1967; You et al. 1993; Hanor 1994; Worden 1996; Dia et al. 1999; Kopf and Deyhle 2002; Kharaka and Hanor 2004; Chung et al. 2015).

Solid phases associated with the discharged fluids, called mud breccia, generally consist of clay-rich mud matrix and heterogenic rock fragments extruded from subsurface plumbing systems of MVs (Dimitrov 2002; Kopf and Deyhle 2002). Clay mineral alteration (e.g. illitization of smectite) is commonly assumed to be related to mud volcanism (Kopf and Deyhle 2002; Lavrushin et al. 2005). Since MVs mainly consist of smectite-rich mud (Fitts and Brown 1999), boron can be adsorbed by this clay mineral and then released to pore fluids through temperature-driven smectite-illite transformation during burial or tectonic processes (Colten-Bradley 1987; You et al. 1996). Consequently, insights into temperatures at depth in the various compressional tectonic settings can be gathered by this element, although boron can also be enriched by degradation of organic matter in buried sediments (Williams et al. 2001; Kharaka and Hanor 2004).

The South Caspian Basin, which includes the Southern Caspian Sea and the coastal zones of Iran, Azerbaijan and Turkmenistan, is one of the oldest gas- and oil-bearing provinces in the world (Smith-Rouch 2006). This basin is well known for a large number of small-to-huge MVs (Figure 1) that occasionally produce impressive eruptions (Planke et al. 2003). These structures predominantly release thermogenic gas and are often found in association with petroleum fields (Fowler et al. 2000).

This paper reports the chemical and isotopic features of hydrocarbon-rich gases and waters, as well as a qualitative estimation of the mud-forming minerals, emitted from four onshore MVs, namely Sofikam, Inche, Gharenyaregh and Neftlijeh (Omrani and Raghimi 2018) which are located in the Gorgan Plain (SE Caspian Sea, Iran), to provide information about the origin and the main geochemical processes controlling fluid geochemistry.

\section{Geological setting}

The South Caspian Basin, one of the deepest sedimentary basins in the world (Devlin et al. 1999), is bounded by Caucasus, Talesh, Alborz and Kopeh Dagh mountains. Sediments derived by erosion and dismantling of these mountain belts fill up the subsiding South Caspian Basin and led, in the Pliocene-Quaternary, to the deposition of thickest sedimentary series at a rate of up to $3 \mathrm{~km} / \mathrm{Ma}$ (Brunet et al. 2003). A thick clay-dominated sedimentary cover (up to $25-30 \mathrm{~km}$ ) and a low geothermal gradient $\left(15-18^{\circ} \mathrm{C} / \mathrm{km}\right)$ characterize the South Caspian Basin. The high sedimentation rate was likely responsible of undercompacted sedimentary sequences, pore water overpressure, maturation of organic material and formation of structural traps, which are typical of mud volcanism areas (Abrams and Narimanov 1997; Tagiyev et al. 1997).

More than 400-active onshore and offshore MVs are present in this region. They are mostly associated with hydrocarbon fields within hydrocarbon-bearing faulted anticlines (Guliyev and Feizullayev 1996; Fowler et al. 2000). The geochemistry of fluids discharged from the South Caspian Basin MVs, including those exposed in Cheleken peninsula (western Turkmenistan) and Azerbaijan were extensively studied (Planke et al. 2003; Davies and Stewart 2005; Mazzini et al. 2009; Oppo et al. 2014; Lavrushin et al. 2015). The Oligocene-Early Miocene Maykop Formation, including layers of anoxic fine-grained and organic-rich sediments (Abrams and Narimanov 1997; Feyzullayev et al. 2001; Hudson et al. 2008), is to be regarded as the main fluid source (Figure 2; Inan et al. 1997; Fowler et al. 2000). However, some clasts found in 


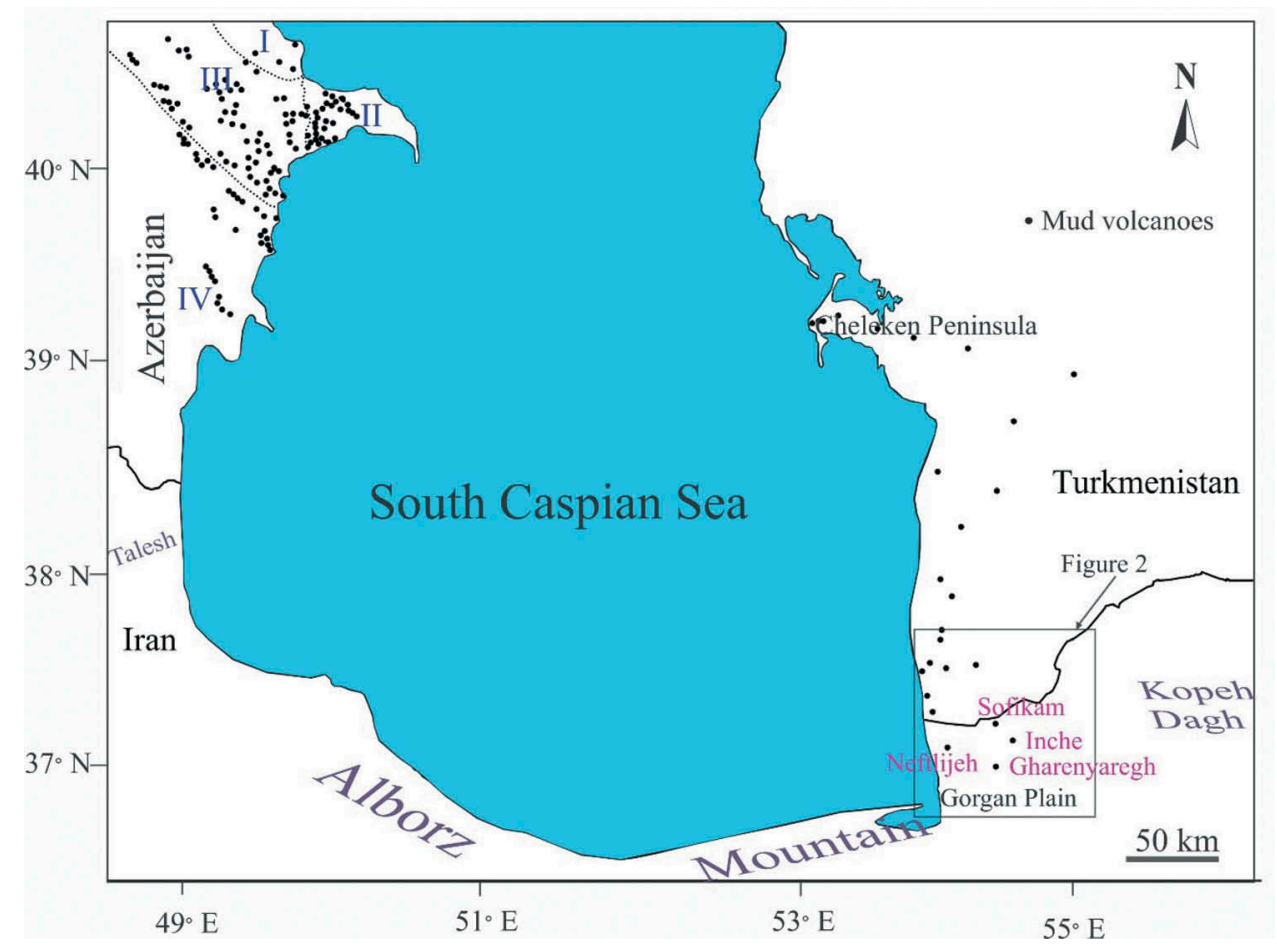

Figure 1. Schematic map showing the location of onshore mud volcanoes in the South Caspian Basin including those of Azerbaijan (mud volcanic regions: (I) Caspian, (II) Absheron, (III) Shemakha-Gobustan and (IV) Kura; Lavrushin et al. 2015; Jakubov et al. 1971), Turkmenistan (Oppo et al. 2014) and Iran.

\begin{tabular}{|c|c|c|}
\hline Epochs & Suites & Lithology \\
\hline Recent & \multirow{2}{*}{ Apsheron } & \\
\hline Pleistocene & & $-1-$ \\
\hline \multirow{10}{*}{$\begin{array}{l}\text { Early } \\
\text { Pliocene } \\
\text { Late } \\
\text { Miocene }\end{array}$} & \multirow{9}{*}{$\begin{array}{l}n \\
0 \\
0 \\
0 \\
0 \\
0 \\
0 \\
2 \\
= \\
0 \\
5 \\
0 \\
0 \\
0 \\
0 \\
0\end{array}$} & 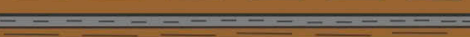 \\
\hline & & $=$ \\
\hline & & $=$ \\
\hline & & $=\overline{-}$ \\
\hline & & 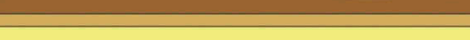 \\
\hline & & 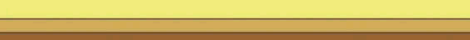 \\
\hline & & מ n \\
\hline & & 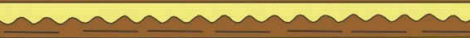 \\
\hline & & $\tilde{m}$ \\
\hline & Diatom & 11 \\
\hline \multirow{2}{*}{$\begin{array}{l}\begin{array}{l}\text { Lower } \\
\text { Miocene }\end{array} \\
\text { Oligocene }\end{array}$} & Diatom & \\
\hline & Maykop & \\
\hline Eocene & \multirow{2}{*}{ Paleogene } & \\
\hline Paleocene & & \\
\hline \multicolumn{3}{|l|}{ Cretaceous } \\
\hline Jurassic & & 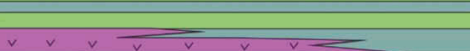 \\
\hline
\end{tabular}

Figure 2. Generalized schematic stratigraphic column of South Caspian Basin (adopted from Green et al. 2009). the mud breccias suggested possible contributions from deeper sedimentary sequences (i.e. Middle-late Miocene Diatom Series and Mesozoic deposits; Guliyev and Feizullayev 1996; Inan et al. 1997; Feyzullayev et al. 2001).

The Gorgan Plain, where MVs of current work presented, is located at $36^{\circ} 40^{\prime}$ to $37^{\circ} 30^{\prime} \mathrm{N}$ and $53^{\circ} 38^{\prime}$ to $55^{\circ} 38^{\prime} \mathrm{E}$ (Figure 3 ) in the Golestan province (NE Iran). The sedimentary successions of this Plain are part of those of the South Caspian and Kopeh Dagh Basins. The Kopeh Dagh Basin, as an elongated E-W trending basin located to the northeast of Iran and east of the South Caspian Basin. The boundary between the thick sedimentary series of South Caspian (Pliocene to Pleistocene) and the faulted and eroded formations of Kopeh Dagh (Jurassic to Eocene) beneath the eastern Gorgan is marked by a major Eocene-Oligocene angular unconformity. Although, above this unconformity, the faulted shale ridge structures on seismic section has been observed which are probably Maykop Formation (Robert et al. 2014). Ongoing geochemical investigations on a newly dug petroleum exploration well located near Sofikam MV also revealed the occurrence of a sequence similar to that characterizing the Maykop formation (Dr M. Mosavi Rohbakhsh; personal communication), the latter being possibly the source rock of gas seepages. 


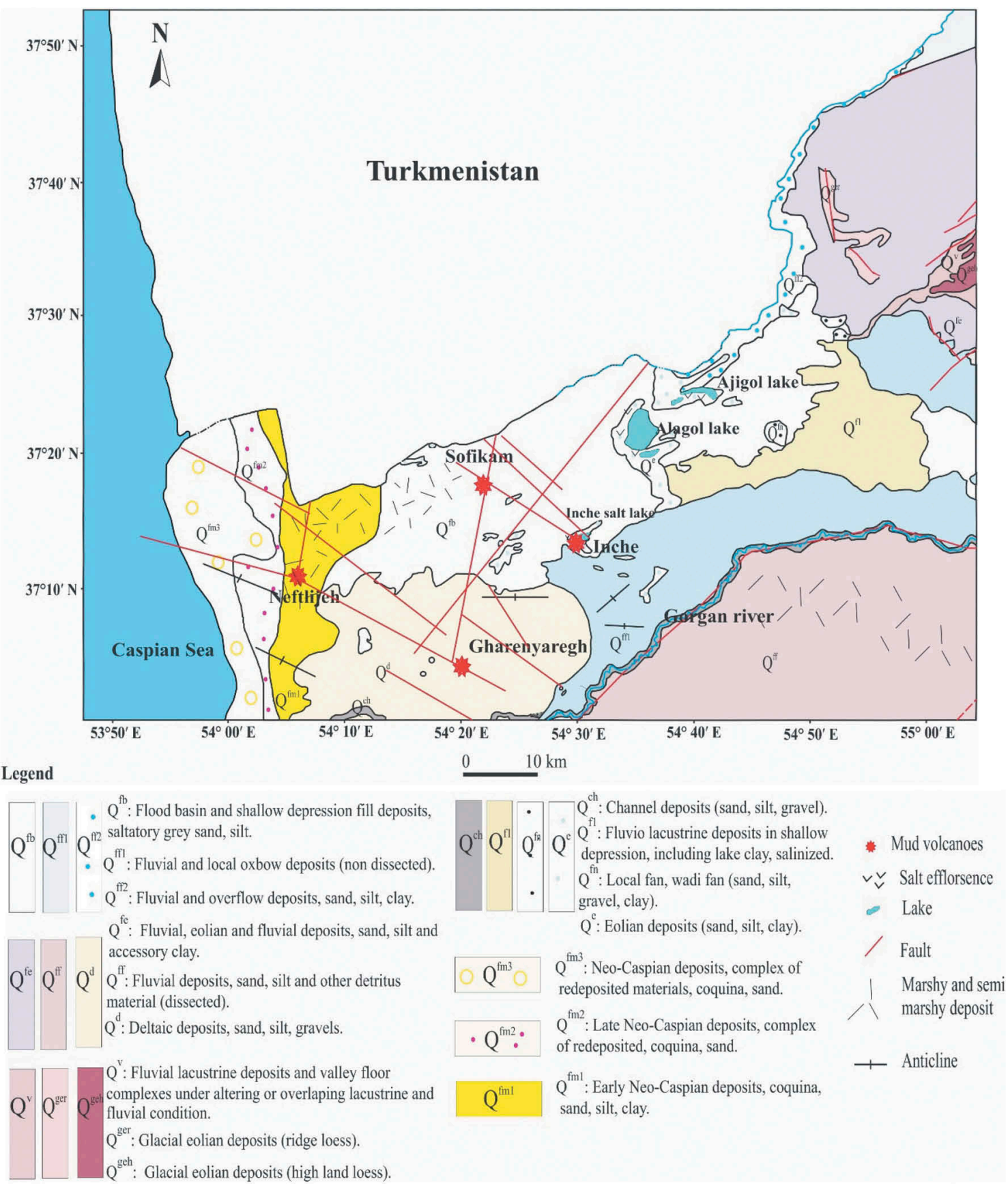

Figure 3. Schematic geological map of southeastern of Caspian Sea, Gorgan Plain, Iran showing the location of investigated MVs (modified after Saeedi and Andalibi 1993) controlled by faults/folds of Kopeh Dagh Basin (adapted from Omrani and Raghimi 2018).

The shale ridge structures are overlain by the Late Miocene yellow horizon and the Pliocene Cheleken formation. In the South Caspian Basin, the main hydrocarbon reservoirs are hosted within the Cheleken formation, which shows an increasing thickness from the Eastern Gorgan Plain towards the Caspian Sea and mainly consists of green or dark red sand-containing marls and thick layers of sandstone and conglomerate deposits (Guliyev and Feizullayev 1996; Abrams and Narimanov 1997; Fowler et al. 2000; Planke et al. 2003;
Stewart and Davies 2006; Torres 2007). An overpressured gas-dominated layer was found in the Cheleken formation during the drilling of two exploration wells located near Gharenyaregh MV in Gorgan Plain. The Cheleken formation is overlain by Late Pliocene claystone and marls with minor interbedded sandstones (Akchagyl Formation), followed by Pleistocene (Apsheron formation) and late Pleistocene-Holocene strata of the Baku, Khazarian, Khvalynian and Neocaspian stages (Mosavi Rohbakhsh 2001). Thin layers of volcanic ashes were 
reported to occur in the Akchagyl and Apsheron formations (Alizadeh et al. 2016). In the Gorgan Plain, wells for gas-oil exploration were drilled at shallow-tointermediate depth $(1,000-3,500 \mathrm{~m})$, revealing the occurrence of microbial methane associated with iodine bearing high-salinity waters hosted within the Akchagyl and Apsheron formations (Mosavi Rohbakhsh 2001; Khajeh et al. 2007).

The buried Mesozoic Kopeh Dagh formations, which outcrop at the eastern part of Gorgan plain, have up to 10-km thickness (Berberian and King 1981). Upper Cretaceous begin with the glauconite sandstones of Aitamir formation and end with limestones of Kalat (Sharafi et al. 2012). Lower Cretaceous begin with the conglomerates and sandstones of the Shurijeh formation and end with the dark-grey shales and siltstones of the Sanganeh (Raisossadat 2004). Jurassic sediments include sandstones and shales of the Kashafrud (Middle Jurassic) are overlain by grey shales and marly limestones of Chaman Bid and the limestone of Mozduran with Upper Jurassic in age. The Kashafrud and Chaman Bid formations are the main source rocks and Tirgan (Lower Cretaceous) and Mozduran formation are the potential and main gas reservoirs in the Kopeh Dagh range, respectively (Robert et al. 2014).

\section{MVs of Gorgan}

Gharenyaregh, Inche, Sofikam and Neftlijeh MVs (Figure $4(a-f))$ formed on the flat Quaternary plain located in the coastal region of South Caspian Sea (Figure 3). In addition, nearly 20 extinct MVs controlled mostly by fault/ fold structures have been reported (Omrani and Raghimi 2018). There are also buried MVs identified during seismic surveys in this area (Rezvandehy et al. 2011).

The morphology of the four MVs was already described by Omrani and Raghimi (2018). All MVs are as caldera-like depressions with limestone blocks within mud island of Gharenyaregh (Figure 4(c)) and concentric ring collapse structures on the outskirts of Neftlijeh (Figure 4(e)) which can be ascribed to intense and persistent mud fluid emissions during the past. Water pools of Gharenyaregh were characterized by dark oily iridescences, whilst bubbling gases released strong smell of rotten eggs (Figure $4(\mathrm{~b})$ ). The rock fragments originating from glauconitic sandstones of the Aitamir Formation (Upper Cretaceous) belonging to underlying Kopeh Dagh units were only found around Gharenyaregh indicating a deep source (Omrani and Raghimi 2018).

The location of MVs coincide with subsurface anticlines and NW-SE and NE-SW trending faults of the western Kopeh Dagh fold-thrust belt (Figure 3). The five pools of the Sofikam define an alignment with northeast direc-

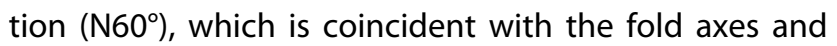
main faults of Kopeh Dagh (Omrani and Raghimi 2018). Several small seeps, approximately $0.5 \mathrm{~m}$ in diameter, occur in the collapsed sectors from the outer flanks of Gharenyaregh along NW-trending faults (Figure $4(a, b)$ ), likely related to the tectonic stress that caused the formation of this MV (Rezvandehy et al. 2011).

\section{Materials and method}

Bubbling gases of the Sofikam, Neftlijeh, Inche and Gharenyaregh MVs were collected in 2017. The first three MVs were sampled using a plastic funnel up-sidedown positioned above the bubbling sites and connected through a silicon tube to a pre-evacuated glass bottle equipped with a thorion valve (Vaselli et al. 2006). Gas sampling from three pools at Gharenyaregh was carried out using 40-mL gas vials equipped with a rubber septum instead of the glass bottle.

The chemical and isotopic $\left(\delta^{13} \mathrm{C}_{1}\right.$ and $\left.\delta^{13} \mathrm{C}-\mathrm{CO}_{2}\right)$ composition of gas was carried out at the Laboratory of Fluid Geochemistry of the Department of Earth Sciences (University of Florence, Italy). The inorganic gas fraction $\left(\mathrm{CO}_{2}, \mathrm{~N}_{2}, \mathrm{Ar}+\mathrm{O}_{2}\right.$ and $\left.\mathrm{H}_{2}\right)$ was analysed by gas chromatography (GC) using a Shimadzu 15A instrument equipped with a Thermal Conductivity Detector (TCD). Argon and $\mathrm{O}_{2}$ were separately analysed using a Thermo Focus gas chromatograph equipped with a $30 \mathrm{~m}$ long capillary molecular sieve column and a TCD. Methane and $\mathrm{C}_{2}-\mathrm{C}_{4}$ hydrocarbons were determined by using a Shimadzu 14A gas chromatograph equipped with a Flame Ionization Detector (FID) and a $10 \mathrm{~m}$ long stainless-steel column packed with Chromosorb PAW 80/100 mesh coated with 23\% SP 1700 (Vaselli et al. 2006). The analytical error for the GC analysis was $\leq 10 \%$. The carbon isotopes in $\mathrm{CO}_{2}$ (expressed as $\delta^{13} \mathrm{C}-\mathrm{CO}_{2} \%$ ov. V-PDB) were determined by using a Finnigan Delta Plus mass spectrometer (MS), after extracting and purifying $\mathrm{CO}_{2}$ by using liquid $\mathrm{N}_{2}$ and $\mathrm{N}_{2}-$ trichloroethylene cryogenic traps (Evans et al. 1998; Vaselli et al. 2006). Internal (Carrara and S. Vincenzo marbles) and international (NB18 and NBS19) standards were used for estimating the external precision. Analytical uncertainty and reproducibility were $\pm 0.05 \%$ and $\pm 0.1 \%$, respectively. The carbon isotopes in $\mathrm{CH}_{4}$ (expressed as $\delta^{13} \mathrm{C}_{1}$ $\%$ vs. V-PDB) were measured by Cavity Ring-Down Spectroscopy (CRDS) using a Picarro G2201-i Analyser. The errors of the CRDS analysis was $<1 \%$ o. In order to avoid interferences, the instrument inlet line was equipped with (i) a Drierite trap and (ii) a copper trap for the removal of water vapour and $\mathrm{H}_{2} \mathrm{~S}$, respectively. According to the operative ranges of the Picarro G2201-i 


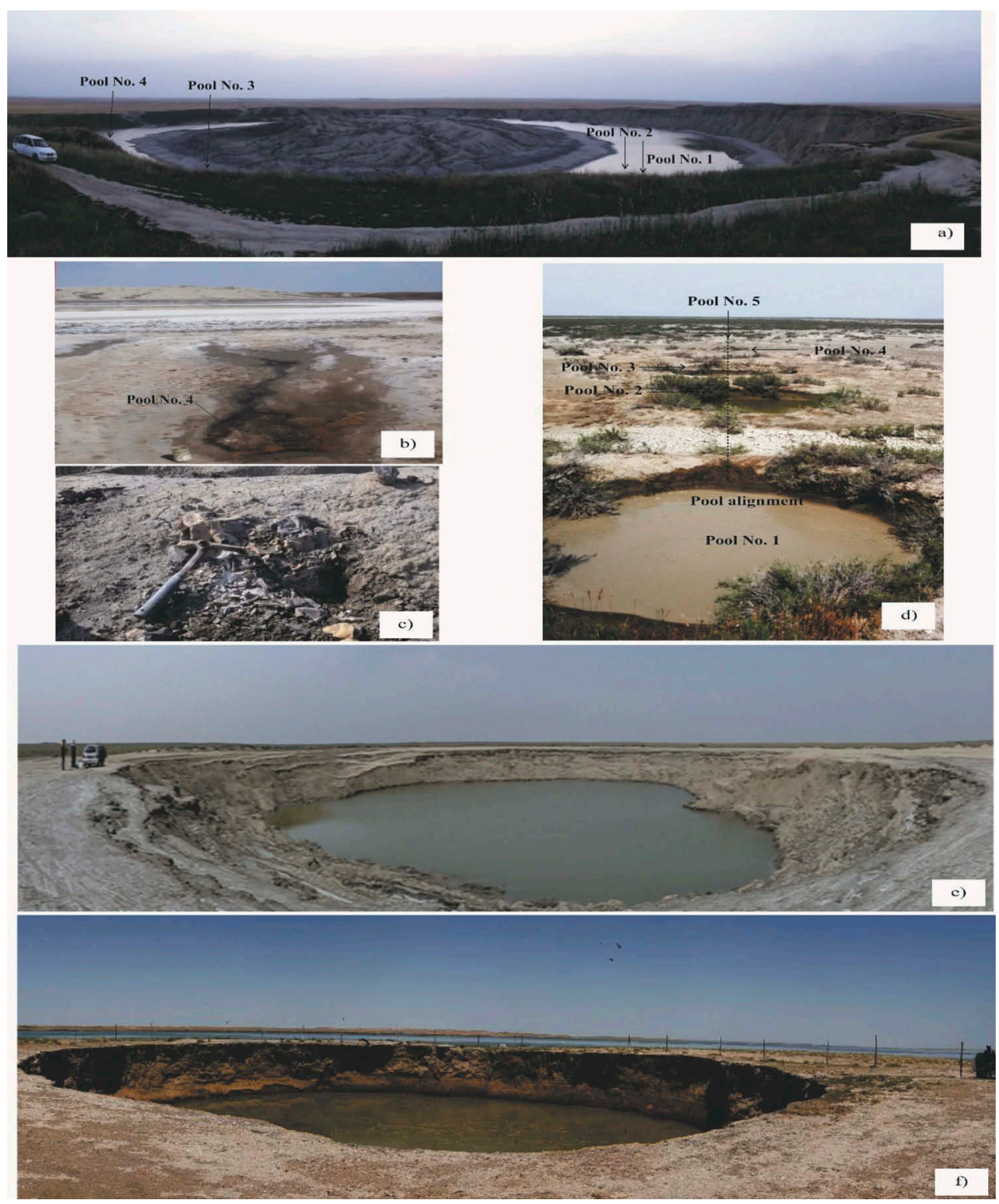

Figure 4. (a) Lateral view of Gharenyaregh MV with a mud island inside, surrounded by a collapsed area filled with saline water and the location of pools (black arrows) probably controlled by a fault, (b) a small seepage (Pool No. 4) within the collapsed area of Gharenyaregh, which is set along other seeps, (c) sedimentary rock fragments within a dried gryphon on island of Gharenyaregh, (d) Sofikam MV showing five pools characterized by permanent fluid emissions define an alignment with northeast direction (N60 ${ }^{\circ}$, which is coincident with the fold axes and main faults of Kopeh Dagh (Omrani and Raghimi 2018), (e) Neftlijeh MV where concentric collapse structures are visible in the left-hand side inner flank, and (f) lateral view of Inche MV.

instrument (up to $500 \mathrm{ppm}$ ), gas samples were diluted using a $\mathrm{N}_{2}-\mathrm{O}_{2}-$ Ar gas mixture.

Water samples were collected from both pools and crater lakes during two campaigns in 2016 and 2017. They were stored in $50-\mathrm{mL}$ polyethylene bottles after filtering at $0.45 \mu \mathrm{m}$ in field for chemical and isotopic analysis. One water sample was taken directly from a well $(1,000-1,200-m$ depth) drilled for iodine extraction from brines near Inche in 2017. At each site, temperature and $\mathrm{pH}$ were measured in the field using an EXTECH ${ }^{\circledR}$ (ExStik ${ }^{\circledR}$ EC500) portable multi-parametric instrument and one filtered and two filtered and acidified (with
Suprapure $\mathrm{HCl}$ and $\mathrm{HNO}_{3}$, respectively) samples were collected.

Analysis on the major components and trace elements of the water were carried out at the Department of Earth Sciences (University of Florence, Italy). Main cations $\left(\mathrm{Na}^{+}, \mathrm{K}^{+}, \mathrm{Ca}^{2+}, \mathrm{Mg}^{2+}\right.$ and $\left.\mathrm{NH}_{4}^{+}\right)$and anions $\left(\mathrm{Cl}^{-}\right.$, $\mathrm{SO}_{4}{ }^{2-}, \mathrm{HCO}_{3}{ }^{-}, \mathrm{NO}_{3}{ }^{-}, \mathrm{Br}^{-}$and $\mathrm{F}^{-}$) were analysed using ion chromatography (Metrohm 861 and 761, respectively). Boron was analysed using the Azomethine-H (AH) method (Bencini 1985) by molecular spectroscopy (MSC) using a Philips UNICAM analyser. The analytical errors for IC and MSC were $\leq 5 \%$. Li concentrations were 
determined by Inductively Coupled Plasma Optical Emission Spectrometry (ICP-OES) using an Optima 8000 Perkin Elmer spectrometer. The analytical error for ICPOES was $\leq 10 \%$. Oxygen (expressed as $\delta^{18} \mathrm{O}-\mathrm{H}_{2} \mathrm{O} \%$ vs. V-SMOW) and hydrogen (expressed as $\delta D-\mathrm{H}_{2} \mathrm{O}$ vs. V-SMOW) analysis were carried out using Finnigan MAT Delta plus XP + Gasbench at G.G Hatch Stable Isotope Laboratory, Faculty of Science, Ottawa University (Canada). The precision (2 sigma) of the analysis was $\pm 0.15 \%$ and $\pm 2.0 \%$ or $\delta{ }^{18} \mathrm{O}-\mathrm{H}_{2} \mathrm{O}$ and $\delta \mathrm{D}-\mathrm{H}_{2} \mathrm{O}$, respectively.

Mineralogical analyses of the powdered mud samples from all four MVs under consideration were carried out at the Department of Earth Sciences (University of Florence) by XRD using a Philips PW 1050/37. In order to separate the $<4 \mu \mathrm{m}$ clay-sized fraction, few grams ( 2 g) of powdered samples were placed in about $50 \mathrm{~mL}$ of MilliQ water, then dispersed by ultrasonic probe and washed and centrifuged at least four times. The wet sediments were transferred to sedimentation cylinders at which $100 \mathrm{~mL}$ MilliQ water was added and allowed it to be settled for $1 \mathrm{~h}$ (Stocks' law). Once the $<4 \mu \mathrm{m}$ clay suspension was recovered and dried, few millilitre of water was added and agitated with a glass rod. About 3-5 $\mathrm{mL}$ of the water-sediment suspension was placed on glass slides and left to be dried at room temperature. The clay minerals were recognized on the dry sample i) without any further treatment; ii) after spraying ethylene glycol; iii) after heating in a ventilated stove at $450^{\circ} \mathrm{C}$ for $1.5 \mathrm{~h}$ and iv) after heating in a ventilated stove at $650^{\circ} \mathrm{C}$ for $1.5 \mathrm{~h}$.

\section{Results}

The chemical (in \% by vol.) and isotopic gas composition are reported in Supp. Table 1. Methane was the dominant alkane in the bubbling vents at Inche (4 samples: from $80.5 \%$ to $93.2 \%$ ), Gharenyaregh (3 samples: from $43.3 \%$ to $80.3 \%$ ), Sofikam (4 samples: from $50.3 \%$ to $84.7 \%)$, and in the Neftlijeh crater lake (1 sample: 90.7\%). Light alkanes (ethane, propane, i-butane and n-butane) had concentrations up to $5.79 \%, 0.89 \%$, $0.35 \%$ and $0.22 \%$, respectively (Supp. Table 1 ). Concentrations of $\mathrm{N}_{2}$ ranged from $1.5 \%$ to $50.0 \%$, whereas those of $\mathrm{O}_{2}$ were $<3.31 \%$.

The $\delta^{13} \mathrm{C}_{1}$ values were in a relatively narrow range: from $-45.6 \%$ o to $-55.1 \%$ vs. V-PDB. The $\delta^{13} \mathrm{C}^{-} \mathrm{CO}_{2}$ values at Sofikam, Gharenyaregh and Inche MVs were from $-17.4 \%$ o to $-26.4 \%$ o vs. V-PDB, whereas that at Neftlijeh was $3.1 \%$ vs. V-PDB.

The chemical and isotopic composition of the waters discharged by Gorgan MVs is listed in Supp. Table 2. The $\mathrm{pH}$ values of the Sofikam, Inche, Gharenyaregh and
Neftlijeh pools and Gharenyaregh lake were up to 7.2, $6.8,7.7,8.9$ and 7.8 , respectively. Considering that the measured temperatures ranged from $24.0^{\circ} \mathrm{C}$ to $30.3^{\circ} \mathrm{C}$ (Supp. Table 2) and that the ambient temperature was from $25^{\circ} \mathrm{C}$ to $31^{\circ} \mathrm{C}$, these emergences cannot be considered as thermal waters. Waters were characterized by a Na-Cl composition, with $\mathrm{Na}^{+}$and $\mathrm{Cl}^{-}$concentrations ranging from 12 to $43.7 \mathrm{~g} / \mathrm{L}$ and from 34.5 to $102 \mathrm{~g} / \mathrm{L}$, respectively. Relatively high concentrations of $\mathrm{NH}_{4}{ }^{+}(19$ to $310 \mathrm{mg} / \mathrm{L})$ were measured. Waters from Gharenyaregh and Neftlijeh showed $\mathrm{HCO}_{3}{ }^{-}$(622 to 2,280 mg/L), Li (16.3 to $25.5 \mathrm{mg} / \mathrm{L}$ ) and B (97 to $1084 \mathrm{mg} / \mathrm{L}$ ) concentrations significantly higher than those recorded at Sofikam and Inche. The former had relatively low concentration of $\mathrm{Ca}^{2+}$ (197 to $855 \mathrm{mg} / \mathrm{L}$ ) and $\mathrm{Mg}^{2+}$ (320 to $914 \mathrm{mg} / \mathrm{L}$ ). Concentrations of $\mathrm{SO}_{4}{ }^{2-}$ in the Gharenyaregh waters (up to $11,240 \mathrm{mg} / \mathrm{L}$ ) were one order of magnitude higher than those measured in the other sites.

The water sample from the iodine production well was $\mathrm{Na}-\mathrm{Cl}$ type and was characterized by relatively high concentration of $\mathrm{Ca}^{2+}(4,900 \mathrm{mg} / \mathrm{L}), \mathrm{Mg}^{2+}$ $(4,650 \mathrm{mg} / \mathrm{L}), \mathrm{Li}(60.3 \mathrm{mg} / \mathrm{L}), \mathrm{NH}_{4}{ }^{+}(423 \mathrm{mg} / \mathrm{L})$ and $\mathrm{SO}_{4}{ }^{2-}$ $(8,620 \mathrm{mg} / \mathrm{L})$.

The $\delta^{18} \mathrm{O}-\mathrm{H}_{2} \mathrm{O}$ and $\delta \mathrm{D}-\mathrm{H}_{2} \mathrm{O}$ values of the Sofikam waters ranged from $-1.78 \%$ to $1.04 \%$ o and from $-30.1 \%$ o to $-17.3 \%$ vs. V-SMOW, respectively. Heavier $\delta^{18} \mathrm{O}-\mathrm{H}_{2} \mathrm{O}$ and $\delta \mathrm{D}-\mathrm{H}_{2} \mathrm{O}$ values were measured in the lakes from Inche $(0.88 \%$ o to $1.11 \%$ and $-16.7 \%$ o to $-15.9 \%$ vs. V-SMOW, respectively), Neftlijeh (3.17\%o to $4.10 \%$ and $-8.9 \%$ to $-10.0 \%$ vs. V-SMOW, respectively) and the Gharenyaregh water pool (1.10\%o to $1.39 \%$ and $-20.0 \%$ o to $-18.2 \%$ vs. V-SMOW, respectively).

Quartz, calcite, halite, muscovite, illite, albite, clinochlore and microcline were found in the mud samples for all the studied MVs. Gypsum was only found in mud samples from Sofikam and Inche MVs, whereas dolomite and traces of marcasite were recognized in the mud samples from Gharenyaregh and Neftlijeh. Clay minerals in the $<4 \mu \mathrm{m}$ fraction were consisting of illite, chlorite and kaolinite with low contents of smectite, with no significant differences among the studied mud samples.

\section{Discussion}

\section{Processes controlling the chemistry of gases}

Gas chemistry from the Gorgan MVs can be related to a mixing process between an $\mathrm{N}_{2}$-rich (air-like) and a $\mathrm{CH}_{4}{ }^{-}$ rich component. The $\mathrm{N}_{2} / \mathrm{Ar}$ ratios range from 51.6 to 79.4 (Supp. Table 1), i.e. between those of air (83.6) and airsaturated water (ASW: 38.3), indicating that both $\mathrm{N}_{2}$ and Ar have a meteoric origin. Considering that deep-originated 
gases feeding $\mathrm{MVs}$ are $\mathrm{O}_{2}$-depleted, the occurrence of $\mathrm{O}_{2}$ $(<3 \%)$ suggests some air contamination at shallow depth and/or during the gas sampling. A significant contribution of mantle $\mathrm{He}$ is to be ruled out due to the low $\mathrm{Rc} / \mathrm{Ra}$ values ranging between 0.08 and 0.12 (Mehrabi et al. 2017).

The $\mathrm{CH}_{4}$-rich component is typical of gases related to mud volcanism occurring in sedimentary basins (e.g. Dia et al. 1999; Dimitrov 2002; Mazzini et al. 2009; Tassi et al. 2012; Bonini et al. 2013). As shown in the $\delta^{13} C_{1}$ vs. $C_{1} /\left(C_{2+}\right)$ binary diagram (Figure 5; Milkov and Etiope 2018), gases from the Gorgan MVs fall in the field of thermogenic gas. It is worth noting that gases from Azerbaijan and Turkmenistan MVs (Etiope et al. 2009a), which are related to a geodynamic setting similar to that of the study area, showed similar $\delta^{13} C_{1}$ values, whereas their $C_{1} /\left(C_{2+}\right)$ ratios were significantly higher than those of the Gorgan Plain gases. Such geochemical features were interpreted as related to secondary processes acting during the uprising of thermogenic gases: (i) molecular fractionation due to the gas transfer from reservoir to surface; (ii) secondary anaerobic biodegradation (Pallasser 2000; Katz et al. 2002; Deville et al. 2003; Etiope et al. 2007, 2009a, 2009b). Secondary anaerobic biodegradation processes were reported to extensively affect also gases from hydrocarbon fields and MVs located in the western sector of South Caspian Sea (Figure 6), showing isotopically heavy $\mathrm{CO}_{2}$

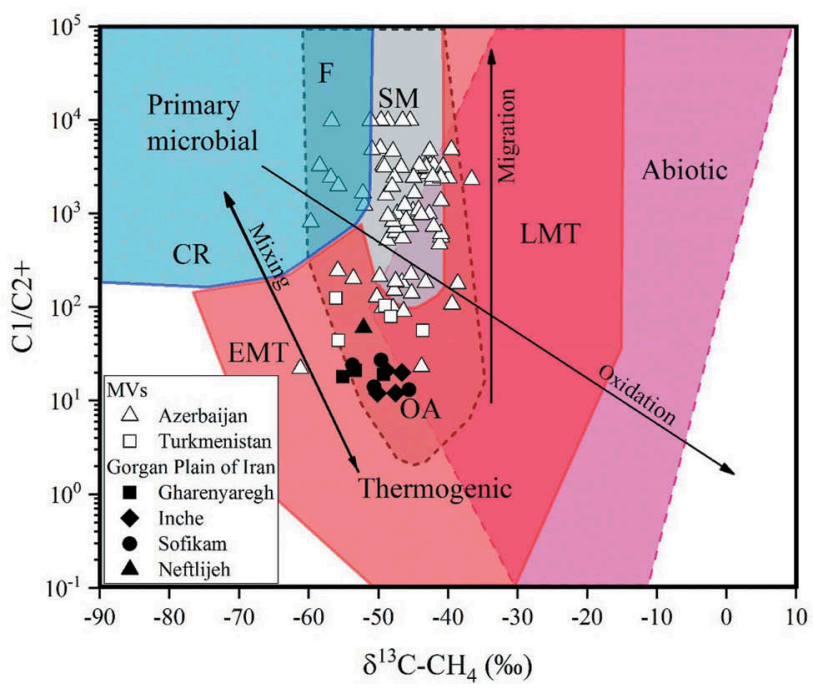

Figure 5. Plot of $C_{1} / C_{2+}$ ratios vs. $\delta^{13} C_{1}$ values for the gases emitted from Sofikam, Gharenyaregh, Inche and Neftlijeh MVs. Typical fields for microbial, thermogenic and abiotic gases (CR $\mathrm{CO}_{2}$ reduction, $\mathrm{F}$ - methyl-type fermentation, $\mathrm{SM}$ - secondary microbial, EMT - early mature thermogenic gas, OA - oilassociated thermogenic gas and LMT - late mature thermogenic gas; Milkov and Etiope 2018) are outlined. The gas data from MVs of Azerbaijan and Turkmenistan (Etiope et al. 2009a, 2009b) are also reported for comparison.

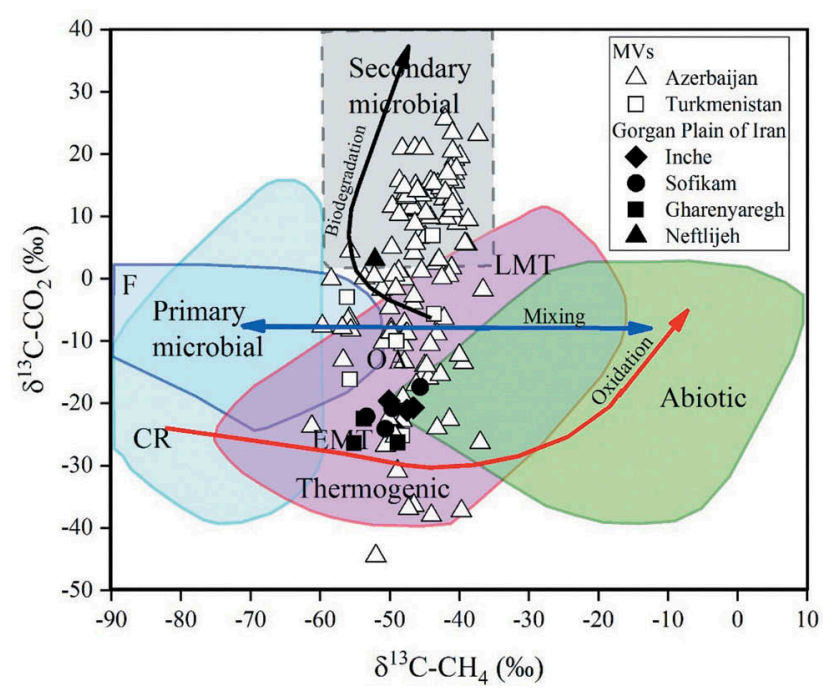

Figure 6. Plot of $\delta^{13} \mathrm{C}_{\mathrm{CH} 4}$ vs. $\delta^{13} \mathrm{C}_{\mathrm{CO} 2}$ values $\left(\mathrm{CR}-\mathrm{CO}_{2}\right.$ reduction, $\mathrm{F}$ - methyl-type fermentation, EMT - early mature thermogenic gas, OA - oil-associated thermogenic gas and LMT - late mature thermogenic gas; Milkov and Etiope 2018) for gases from Gorgan MVs and those from Azerbaijan and Turkmenistan MVs (Etiope et al. 2009b) for comparison.

(Feyzullayev and Movsumova 2001). This feature is typical of gases from petroleum reservoirs located at shallow depths $(<2000 \mathrm{~m})$ and relatively low temperatures $\left(<75^{\circ} \mathrm{C}\right)$, where water temperature and availability of oxyanions $\left(\mathrm{NO}_{3}{ }^{-}, \mathrm{SO}_{4}{ }^{2-}\right.$ and $\left.\mathrm{HCO}_{3}{ }^{-}\right)$can play a key role in the gas evolution (Pallasser 2000). $\mathrm{CO}_{2}$ generated by anaerobic oxidation of petroleum or heavy hydrocarbons is consumed by methanotrophs (Pallasser 2000; Head et al. 2003; Jones et al. 2008; Milkov 2011, 2018). The residual ${ }^{12} \mathrm{C}$-depleted $\mathrm{CO}_{2}$ is highly indicative of secondary microbial methane formed during petroleum biodegradation (Milkov 2011, 2018). Among the South Caspian gases, secondary anaerobic biodegradation and the occurrence of secondary microbial methane is only documented by the composition of Neftlijeh gas sample, which was characterized by a positive $\delta^{13} \mathrm{C}^{-} \mathrm{CO}_{2}$ value (Figure 6). Contrarily to the Azerbaijan gases, those from Gorgan Plain seem to be poorly affected by molecular fractionation. This occurs in the presence of high gas fluxes or when the distance from the reservoir to the surface is rather short. In both cases, gas-water-mud interactions leading to loss of $\mathrm{C}_{2+}$ compounds are kinetically disadvantaged and thus, they do not affect the ascending gas (Etiope et al. 2007, 2009b).

There are two geological evidences suggesting that thermogenic source play a key role in the formation of the Gorgan Plain gases: (i) the gas layers recognized by geophysical investigations in the Cheleken formation around the Gharenyaregh MV (Rezvandehy et al. 2011), 
and (ii) the potential source rock formations recently identified in wells drilled and on seismic sections in the study area, which are similar to the Maykop formation and Middle Miocene-Late Miocene deposits and probably buried Mesozoic sediments of Kopeh Dagh Basin. Sedimentary basins and MVs from the South Caspian Basin include four potential fluid source rocks; i) Palaeogene-Lower Miocene marine mudstones, comprising organic-rich fine-grained, clay-dominated layers with fine to very fine sandstone strata and dolomite-rich beds, ii) Middle-Late Miocene shales and marls interbedded with sandstones and siltstones with diatom suite, iii) Lower Cretaceous greyish-green claystone, yellowish-red sandstones and subordinate conglomerates and iv) Middle Jurassic sedimentary sequences consisting of clay-rich facies interbedded with fine grained sandstones and siltstones (Inan et al. 1997; Feyzullayev et al. 2001; Guliyev et al. 2004; Hudson et al. 2008; Bonini et al. 2013).

\section{Water geochemistry and mud mineralogy}

The waters collected from the Gorgan Plain MVs have a relatively high TDS values (44-127 g/L), higher than those of water emergencies located in adjacent areas, e.g. Turkmenistan, where the TDS values were from 23 to $50.7 \mathrm{~g} / \mathrm{L}$ (Oppo et al. 2014), and a $\mathrm{Na}^{+}-\mathrm{Cl}^{-}$composition (Supp. Table 2), typical of a brine (Hem 1970).

The occurrence of brines in sedimentary basins is commonly attributed to halite dissolution (Dresel and Rose 2010; Pinti et al. 2011) or seawater trapped in geological formations (Birkle et al. 2009; Lüders et al. 2010). Seawater evaporation trend (SET) has extensively been applied to determine the origin of salinity in sedimentary basins (Bottomley et al. 1999; Kharaka and Hanor 2004). Gorgan waters follow SET (Figure 7), although variations in the $\mathrm{Cl}^{-} / \mathrm{Br}^{-}$ratios were likely caused by the concomitant evaporation and halite dissolution (Knauth 1988).

Brine chemistry from oilfields is controlled by a variety of physical processes such as mixing between deep and shallow waters and chemical reactions such as mineral dehydration, adsorption and desorption on clay minerals, precipitation and dissolution of carbonate minerals and degradation of organic material leading to increasing alkalinity, $\mathrm{NH}_{4}^{+}, \mathrm{B}$ and $\mathrm{Br}^{-}$and decreasing concentration of oxidized species such as $\mathrm{SO}_{4}{ }^{2-}$ (Kharaka and Smalley 1976; Lagunova 1976; You et al. 1993; Kopf and Deyhle 2002).

Chloride shows a conservative chemical behaviour in pore waters and its distribution in fluids from MVs can provide useful insights into the water sources. The TDS

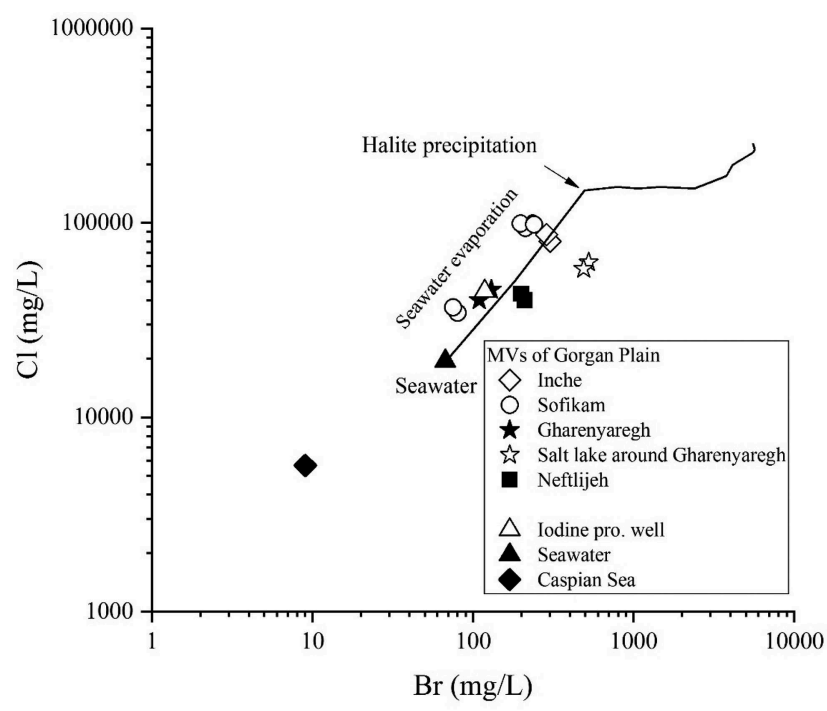

Figure 7. $\mathrm{Cl}$ vs. $\mathrm{Br}$ (in $\mathrm{mg} / \mathrm{L}$ ) in water from the Gorgan MVs and the iodine production well. The evaporation trend for seawater and water composition of the Caspian Sea are from Carpenter (1978) and Planke et al. (2003).

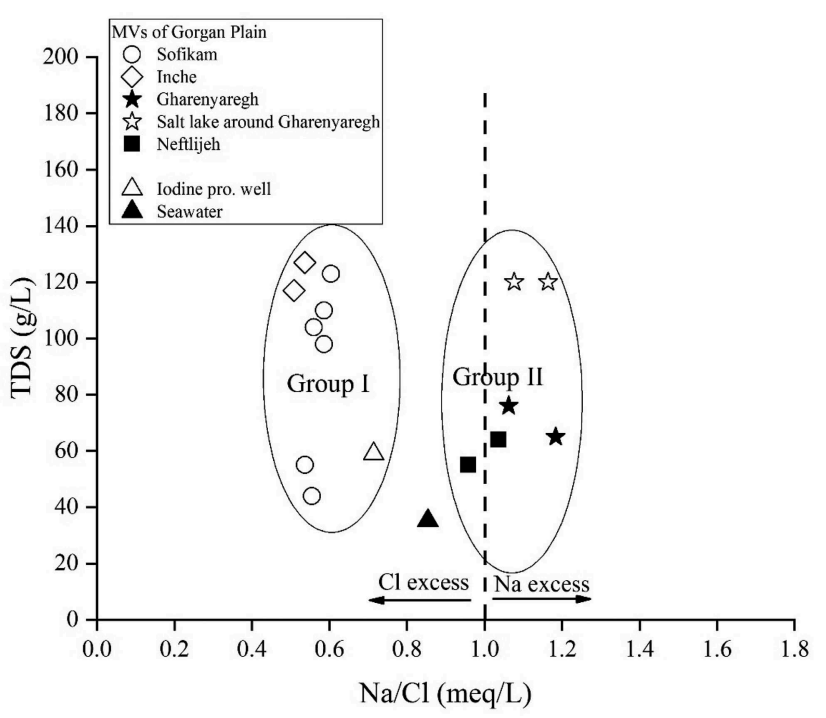

Figure 8. TDS (in $\mathrm{g} / \mathrm{L}$ ) vs. $\mathrm{Na} / \mathrm{Cl}$ (in $\mathrm{meq} / \mathrm{L}$ ) plot for waters from the Gorgan MVs, the iodine production well and seawater (Fontes and Matray 1993). Gorgan waters are divided to two groups I (Inche and Sofikam MVs) and II (Gharenyaregh and Neftlijeh MVs) according to $\mathrm{Cl}$ and $\mathrm{Na}$ excess.

versus $\mathrm{Na}^{+} / \mathrm{Cl}^{-}$plot (Figure 8), as well as the ratios between $\mathrm{Cl}^{-}$and the main cations $\left(\mathrm{Na}^{+}, \mathrm{Ca}^{2+}, \mathrm{Mg}^{2+}, \mathrm{K}^{+}\right.$, and $\left.\mathrm{Li}^{+}\right)$and B (Figure 9 and Supp. Table 2), allow to distinguish two groups: i) waters from Gharenyaregh and Neftlijeh MVs, which are characterized by $\mathrm{Na}^{+} / \mathrm{Cl}^{-}, \mathrm{B} / \mathrm{Cl}^{-}$and $\mathrm{Li} / \mathrm{Cl}^{-}$ratios similar or higher than those of seawater, and relatively low $\mathrm{Ca}^{2+} / \mathrm{Cl}^{-}, \mathrm{Mg}^{2+} / \mathrm{Cl}^{-}$and $\mathrm{K}^{+} / \mathrm{Cl}^{-}$ratios; ii) waters from 


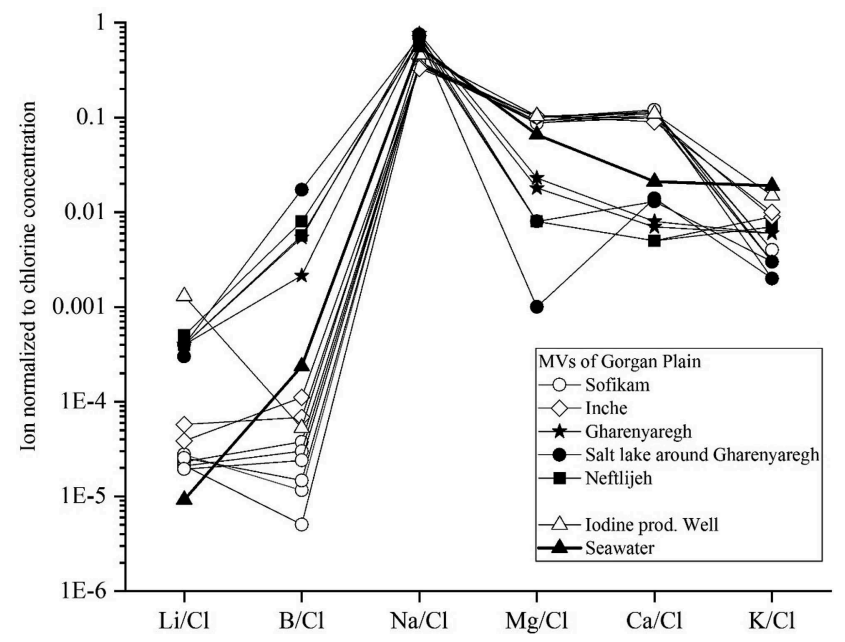

Figure 9. Elemental concentration normalized to chlorine. The concentrations are in logarithmic scale. Seawater is shown.

Sofikam and Inche MVs and the iodine production well, which show significantly lower $\mathrm{Na}^{+} / \mathrm{Cl}^{-}, \mathrm{B} / \mathrm{Cl}^{-}$and $\mathrm{Li} / \mathrm{Cl}^{-}$ and higher $\mathrm{Ca}^{2+} / \mathrm{Cl}^{-}, \mathrm{Mg}^{2+} / \mathrm{Cl}^{-}$and $\mathrm{K}^{+} / \mathrm{Cl}^{-}$ratios.

Lithium, $\mathrm{Na}$ and $\mathrm{B}$, which tend to be enriched in lowtemperature clay minerals (Schwarcz et al. 1969; Spivack et al. 1987; Chan et al. 2002) can enter the aqueous media through (i) hydrothermal alteration at moderate temperatures (around $50^{\circ} \mathrm{C}$ ) (You et al. 1996; James et al. 2003), (ii) desorption and mineral dehydration reactions and (iii) decomposition of organic compounds during burial in response to increasing temperatures (James and Palmer 2000; Williams et al. 2001; Kopf and Deyhle 2002; Kharaka and Hanor 2004; Teichert et al. 2005). An enrichment in these elements, as shown by the Gharenyaregh and Neftlijeh waters, is thus to be considered a common feature for oilfield brines (Bottomley et al. 1999; Chan et al. 2002), suggesting long fluid circulation to reach great depths. Specifically, the high $\mathrm{B} / \mathrm{Cl}^{-}$ratios of these waters (Supp. Table 2 ) were possibly caused by the release of $B$ due to smectite illitization, a typical process occurring during sediment diagenesis, in analogy to what reported for other MVs worldwide (You et al. 1996, 2004; Williams et al. 2001; Kopf and Deyhle 2002; Aloisi et al. 2004; Hensen et al. 2004; Lavrushin et al. 2005; Teichert et al. 2005; Mazzini et al. 2009; Chao et al. 2011). This process is also supported by the qualitatively-estimated scarce content of smectite with respect to that of illite in the muds. The relatively high $\mathrm{Ca}^{2+}$ concentrations and $\mathrm{Na}^{+}$and $\mathrm{K}^{+}$depletion characterizing the second group of waters is typically produced by fluid interaction with igneous rocks due to volcanic ash alteration (Gieskes et al. 1989; You et al. 2004), as also supported by experimental investigations carried out at relatively low $\left(70^{\circ} \mathrm{C}\right)$ temperature (Henderson 1982). Sofikam and Inche fluids likely interacted with the volcanogenic products occurring within the shallow formations of Akchagyl and Apsheron (Alizadeh et al. 2016). However, this process causes a decrease in $\mathrm{Mg}^{2+} / \mathrm{Cl}^{-}$ratio, in contrast with the relatively high $\mathrm{Mg}^{2+} / \mathrm{Cl}^{-}$measured in these waters. The opposite trend identified in waters emitted by these MVs is apparently pointing to another process able to control the Mg content in these waters. The presence of minerals belonging to the chlorite-group (clinochlore), mica and carbonate minerals recognized by XRD in the muds, can likely be representing a potential source of $\mathrm{Mg}^{2+}$, able to explain the high content of $\mathrm{Mg}$ recorded in these waters (White 1965).

The relatively high concentrations of $\mathrm{NH}_{4}{ }^{+}$shown by all the Gorgan Plain waters (19 to $310 \mathrm{mg} / \mathrm{L}$; Supp. Table 2) were likely caused by degradation of organic $\mathrm{N}$-bearing compounds or ion exchange processes with the associated hydrocarbons, as also documented in many waters associated with oilfields (Collins 1975), as well as those discharged from Turkmenistan MVs (Oppo et al. 2014).

Although no $\mathrm{H}_{2} \mathrm{~S}$ measurements were carried out in the present study, the occurrence of this compound in the Gharenyaregh and Neftlijeh MVs was suggested by the strong smell of rotten eggs detected during the geochemical survey. This implies that $\mathrm{SO}_{4}{ }^{2-}$ in the $\mathrm{MV}$ waters may be reduced to $\mathrm{H}_{2} \mathrm{~S}$ by microbial activity, as follows (Friedman et al. 1992):

$$
\mathrm{SO}_{4}^{2-}+2 \mathrm{H}_{2} \mathrm{O}+2 \mathrm{C}_{\text {org }} \rightarrow \mathrm{H}_{2} \mathrm{~S}+2 \mathrm{HCO}_{3}^{-}
$$

This process is also supported by the presence of marcasite revealed by $\mathrm{X}$-ray analysis. Nevertheless, secondary $\mathrm{SO}_{4}{ }^{2-}$ could be produced through $\mathrm{H}_{2} \mathrm{~S}$ oxidation at relatively shallow depth.

In the $\delta \mathrm{D}-\mathrm{H}_{2} \mathrm{O}$ vs. $\delta^{18} \mathrm{O}-\mathrm{H}_{2} \mathrm{O}$ diagram (Figure 10 ), where the local-meteoric water line (LMWL; Shamsi and Kazemi 2014) was reported, the Gorgan Plain waters were compared to those from Azerbaijan (Lavrushin et al. 2015) and Turkmenistan MVs (Lavrushin et al. 2005). The Gorgan Plain waters show significant enrichments in $\delta^{18} \mathrm{O}$ and $\delta \mathrm{D}$ values with respect to $L M W L$ and seem to be aligned along an evaporation trending line. Furthermore, the $\delta^{18} \mathrm{O}$ values are slightly more negative with respect to those of Azerbaijan and Turkmenistan. The isotopic trend depicted by the Gorgan Plain waters is thus possibly related to an evaporation process of seawater diluted by a relatively negative meteoric water (with $\delta^{18} \mathrm{O}$ and $\delta \mathrm{D}$ values of $\sim-12$ and $-80 \%$, respectively). However, isotopic exchange with the mud- 


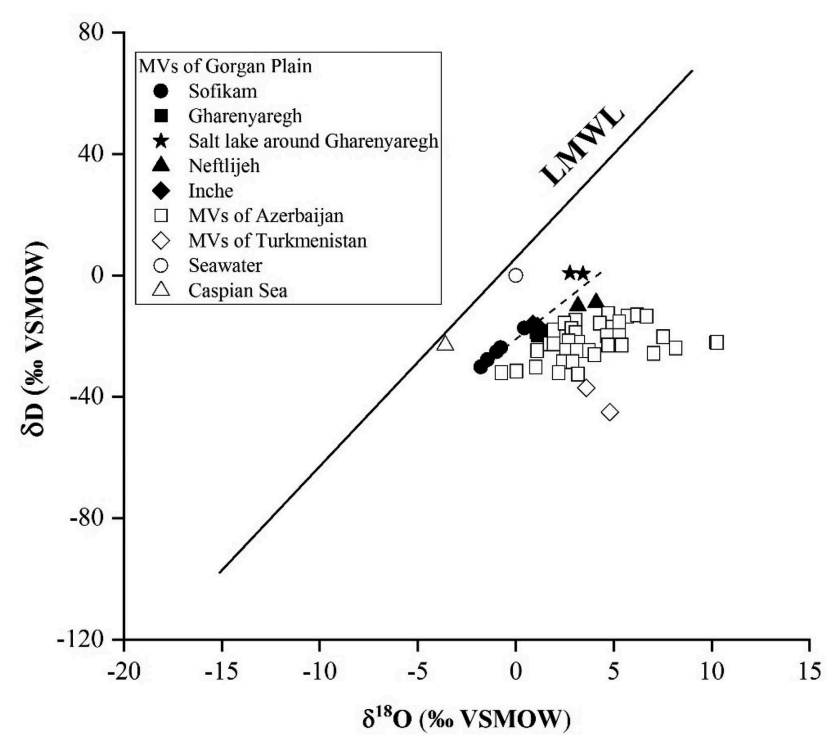

Figure 10. $\delta D$ vs. $\delta^{18} \mathrm{O}$ values of MV waters from Gorgan Plain, Azerbaijan, Turkmenistan, Caspian Sea and Seawater (Lavrushin et al. 2005, 2015) compared with the Local Meteoric Water Line (LMWL) (Shamsi and Kazemi 2014). The dashed line refers to the isotopic variation trend of the Gorgan Plain MVs.

hosting clay minerals (e.g. kaolinite and illite), resulting in an ${ }^{18} \mathrm{O}$-shift, cannot be excluded (e.g. James and Baker 1976; Horbe 2011; Skelton et al. 2019).

Temperature-dependent specific cation pairs in solution can usefully be applied to estimate the temperature of subsurface waters (e.g. Giggenbach 1997; Haese et al. 2006). However, the typical approach proposed by Giggenbach (1992), based on the combined $\mathrm{Na} / \mathrm{K}$ and $\mathrm{K} / \mathrm{Mg}$ geothermometer, cannot be applied due to the contribution of $\mathrm{Na}$ and $\mathrm{Cl}$ from halite and/or seawater. The Mg$\mathrm{Li}$ geothermometer is considered to be able to provide reliable temperature estimations for brines from MVs (Lavrushin et al. 2015, Kharaka and Mariner 1989) as follows:

$$
\mathrm{T}^{\circ} \mathrm{C}=2200 / \log (\log ((\sqrt{\mathrm{Mg}})) / \mathrm{Li}+5.47)-273.15
$$

The Mg- $\mathrm{Li}$ calculated temperatures range from $33^{\circ} \mathrm{C}$ to $40,44^{\circ} \mathrm{C}$ to $53,110^{\circ} \mathrm{C}$ to 117 and $129^{\circ} \mathrm{C}$ to 134 for Sofikam, Inche, Gharenyaregh and Neftlijeh MVs, respectively. Considering an average geothermal gradient of $15-18^{\circ} \mathrm{C} / 1000 \mathrm{~m}$ (Tagiyev et al. 1997) and an average-ground temperature of $16.4^{\circ} \mathrm{C}$ (Kordjazi et al. 2014), these equilibrium temperatures can be attained from $1 \mathrm{~km}$ for Sofikam and Inche to 6-km depth for Gharenyaregh and Neftlijeh. Owing to $\mathrm{Mg}$ in the Sofikam and Inche waters may originate from multiple sources as well as a mixture source for waters, hence, theoretical temperatures for these two MVs calculated using the $\mathrm{Mg} / \mathrm{Li}$ geothermometer is doubtable and should be considered with caution. Notwithstanding the uncertainty of obtained temperature estimations, the geochemical features of the Sofikam and Inche are similar to those shown by brines recognized in the Akchagyl and Apsheron formations during drilling for iodine extraction at 1-km depth (Khajeh et al. 2007) and a deep source for Gharenyaregh (Omrani and Raghimi 2018) are in agreement with the results of the Mg-Li geothermometer.

\section{Model and concluding remarks}

Gases, waters and muds emitted from four MVs located in the Gorgan Plain, SE Caspian Sea (Iran) were collected for chemical and isotopic analysis to investigate their origin and the processes controlling their chemistry. Conceptual models summarizing the main findings gathered from fluid geochemistry of MVs in the Gorgan Plain are reported in Figure 11(a,b). Sofikam, Gharenyaregh, Inche and Neftlijeh MVs have calderalike features and the chemical composition of light alkanes and the isotopic values of methane indicate thermogenic origin for the discharged gases. The Maykop, Upper-Middle Miocene and Mesozoic deposits may be regarded as the probable source rocks for thermogenic gases, although the source rock/s producing thermogenic gas is still questionable due to the complexities and ambiguities in identifying the geological sequences beneath the Gorgan Plain.

The $\mathrm{Na}-\mathrm{Cl}$ waters can be divided into two main groups: Type 1 waters from Gharenyaregh and Neftlijeh MVs showing relatively high $\mathrm{Na}^{+} / \mathrm{Cl}^{-}, \mathrm{B} / \mathrm{Cl}{ }^{-}$and $\mathrm{Li} / \mathrm{Cl}^{-}$ratios and low $\mathrm{Ca}^{2+} / \mathrm{Cl}^{-}, \mathrm{Mg}^{2+} / \mathrm{Cl}^{-}$and $\mathrm{K}^{+} / \mathrm{Cl}^{-}$ratios, typically discharged by MVs due to interaction with marine sediments: These waters likely originate from the deep subsurface formations of Gorgan Plain (Mesozoic formation?). Type 2 waters from Sofikam and Inche MVs are characterized by lower $\mathrm{Na}^{+} / \mathrm{Cl}^{-}, \mathrm{B} / \mathrm{Cl}^{-}$and $\mathrm{Li} / \mathrm{Cl}^{-}$ratios and higher $\mathrm{Ca}^{2+} / \mathrm{Cl}^{-}, \mathrm{Mg}^{2}$ ${ }^{+} / \mathrm{Cl}^{-}$and $\mathrm{K}^{+} / \mathrm{Cl}^{-}$ratios, possibly due to interaction with volcanic rocks and siliciclastic sediments in relatively shallow formations. The relatively high-estimated temperatures for waters from Gharenyaregh and Neftlijeh MVs suggest that they are fed by deep reservoirs ( 6 km).

The positive $\delta^{18} \mathrm{O}$ - and $\delta \mathrm{D}$-shifts measured in all the Gorgan waters are likely caused by (i) evaporation processes affecting seawater diluted by a meteoric component and/or (ii) isotope exchange with the mud-hosting clay minerals.

Integration of the information gathered from the geochemical data of the present study with a comprehensive geological, geostructural and geophysical investigation is 

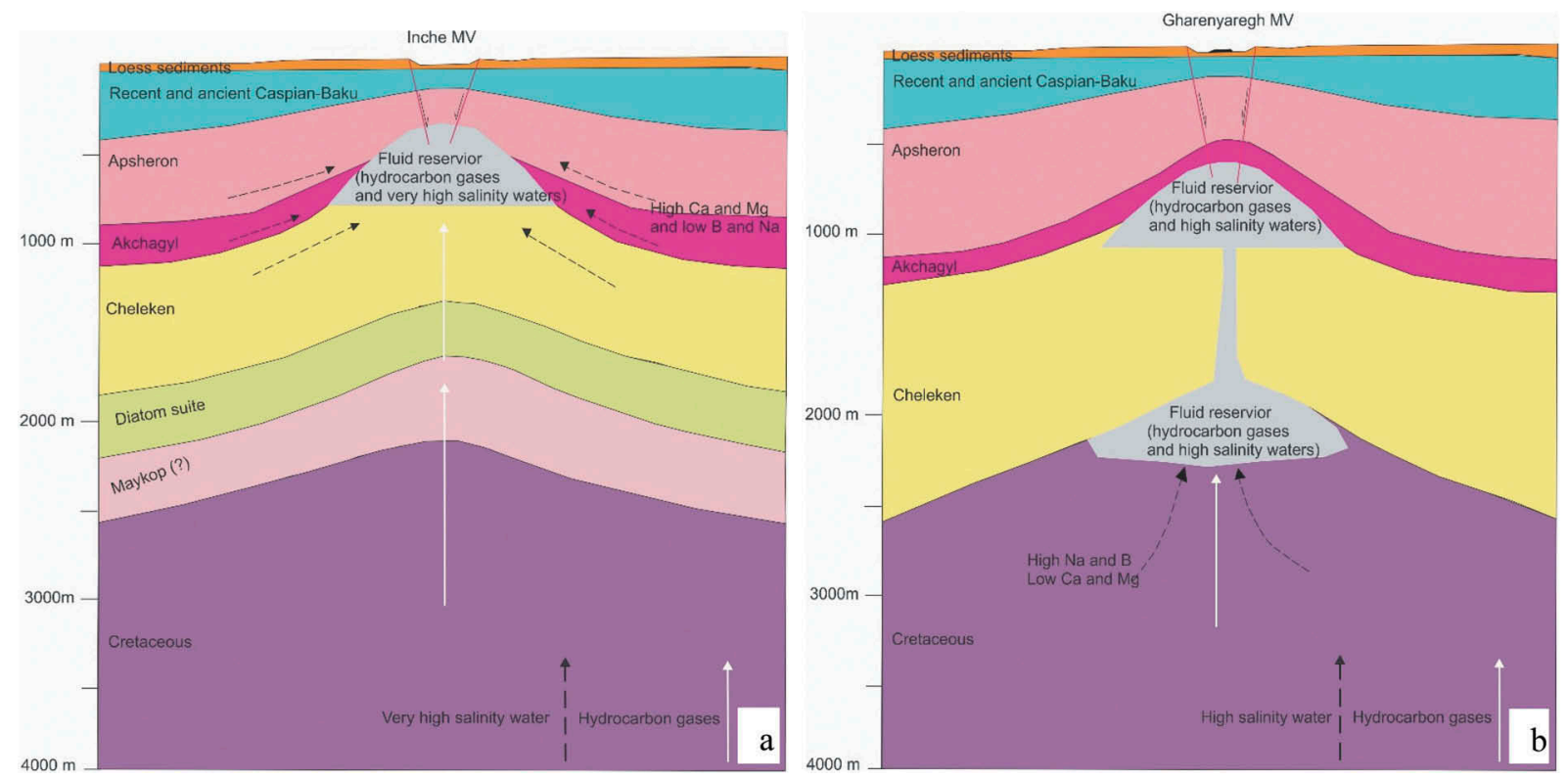

Figure 11. Schematic diagrams show main elements of (a) Inche and (b) Gharenyaregh MVs. The type 1 waters discharging by Gharenyaregh and Neftlijeh MVs may have derived from deep mud-rich layers where acquired the high B concentration from clay minerals transformation. The occurrence of a reservoir at deep layers is also testified by the presence of rock fragments belong to Cretaceous deposits in mud breccia (Omrani and Raghimi 2018). In contrast, the type 2 waters expelling by Incheh and Sofikam MVs may have originated from the relatively shallow reservoirs. In addition to Mesozoic deposits can be regarded as source rocks likely generating the thermogenic gases in Gharenyaregh and Neftlijeh MVs, as they have been observed through the seismic profiles around Gharenyaregh MV (Rezvandehy et al. 2011), the Maykop and Middle-Late Miocene sequences reported in the drilled wells around Incheh and Sofikam MVs (adapted from logs of the drilled wells for hydrocarbon exploration and Robert et al. 2014), can be considered as another probable source rocks.

invoked to constrain the potential hydrocarbon resource of the study areas.

\section{Highlights}

- Mud volcanoes of Northern Iran release thermogenic gases with no secondary isotope fractionation.

- Waters were distinguished in two groups based on the estimated depth of the fluid sources.

- Discharged waters originated from seawater affected by evaporation and dilution processes.

\section{Acknowledgments}

We gratefully acknowledge partial financial support from Iran National Science Foundation, the Office of President, vicePresidency for Science and Technology (project number 95850069). E. Calvi (CNR-IGG of Pisa, Italy) is thanked for carrying out the measurements of the carbon isotopic ratios. We sincerely appreciate Prof. Robert J. Stern, Dr Alexei V. Milkov and Dr Daniele for their critical comments and fruitful suggestions that help improve the quality of this manuscript.

\section{Disclosure statement}

No potential conflict of interest was reported by the authors.

\section{Funding}

This work was supported by the Iran National Science Foundation [95850069];

\section{ORCID}

Jacopo Cabassi iD http://orcid.org/0000-0001-7778-8498

Elena Pecchioni (D) http://orcid.org/0000-0003-1231-8625

Ata Shakeri (iD) http://orcid.org/0000-0001-6913-0784

\section{References}

Abrams, M.A., and Narimanov, A.A., 1997, Geochemical evaluation of hydrocarbons and their potential sources in the western South Caspian depression, Republic of Azerbaijan: Marine and Petroleum Geology, v. 14, p. 451-468. doi: 10.1016/S0264-8172(97)00011-1.

Alizadeh, A., Guliyev, I.S., Kadirov, F.A., and Eppelbaum, L.V., 2016, Geosciences of Azerbaijan, Volume I: Geology: Switzerland, Springer, p. 31-86.

Aloisi, G., Drews, M., Wallmann, K., and Bohrmann, G., 2004, Fluid expulsion from the Dvurechenskii mud volcano (Black Sea) Part I. Fluid Sources and Relevance to Li, B, Sr, I and Dissolved Inorganic Nitrogen Cycles: Earth and Planetary Science Letters, v. 225, p. 347-363. doi: 10.1016/j.epsl.2004.07.006.

Bencini, A., 1985, Applicabilità del metodo dell'Azometina-H alla determinazione del boro nelle acque naturali: 
Rendiconti Della Società Italiana Di Mineralogia E Petrologia, v. 40, p. 311-316.

Berberian, M., and King, G.C.P., 1981, Towards a paleogeography and tectonic evolution of Iran: Canadian Journal of Earth Science, v. 18, p. 1764-1766. doi: 10.1139/e81-019.

Bernard, B.B., Brooks, J.M., and Sackett, W.M., 1978, Light hydrocarbons in recent Texas continental shelf and slope sediments: Journal of Geophysical Research, v. 83, p. 4053-4061. doi: 10.1029/JC083iC08p04053.

Birkle, P., Garcia, B.M., and Padrón, C.M.M., 2009, Origin and evolution of formation water at the Jujo-Tecominoacán oil reservoir, Gulf of Mexico, part 1: Chemical evolution and water-rock interaction: Applied Geochemistry, v. 24, p. 543-554. doi: 10.1016/j.apgeochem.2008.12.009.

Bonini, M., Tassi, F., Feyzullayev, A.A., Aliyev, C.S., Capecchiacci, F., and Minissale, A., 2013, Deep gases discharged from mud volcanoes of Azerbaijan: New geochemical evidence: Marine and Petroleum Geology, v. 43, p.450-463. doi: 10.1016/j.marpetgeo.2012.12.003.

Bottomley, D.J., Katz, A., Chan, L.H., Starinsky, A., Douglas, M., Clark, I.D., and Raven, K.G., 1999, The origin and evolution of Canadian Shield brines: Evaporation or freezing of seawater? New lithium isotope and geochemical evidence from the Slave craton: Chemical Geology, v. 155, p. 295-320. doi: 10.1016/S0009-2541(98)00166-1.

Brunet, M., Korotaev, M., Ershov, A., and Nikishin, A., 2003, The South Caspian Basin: A review of its evolution from subsidence modeling: Sedimentary Geology, v. 156, p. 119-148. doi: 10.1016/S0037-0738(02)00285-3.

Carpenter, A.B., 1978, Origin and chemical evolution of brines in sedimentary basins: Oklahoma Geological Survey Circular, v. 79, p. 60-77. doi: 10.1016/S0037-0738(02)00285-3.

Chan, L.H., Starinsky, A., and Katz, A., 2002, The behavior of lithium and its isotopes in oilfield brines: Evidence from the HeletzKokhav field, Israel: Geochimica et cosmochimica ACTA, v. 66 (4), p. 615-623. doi: 10.1016/S0016-7037(01)00800-6.

Chao, H.C., You, C.F., Wang, B.S., Chung, C.H., and Huang, K.F., 2011, Boron isotopic composition of mud volcano fluids: Implications for fluid migration in shallow subduction zones: Earth and Planetary Science Letters, v. 305, p. 32-44. doi: 10.1016/j.epsl.2011.02.033.

Chung, H.M., Gormly, J.R., and Squires, R.M., 1988, Origin of gaseous hydrocarbons in subsurface environments: Theoretical considerations of carbon isotope distribution: Chemical Geology, v. 71, p. 97-103. doi: 10.1016/00092541(88)90108-8.

Chung, S.Y., Venkatramanan, S., Kim, T.H., Kim, D.S., and Ramkumar, T., 2015, Influence of hydrogeochemical processes and assessment of suitability for groundwater uses in Busan City Korea: Environment, Development and Sustainability, v. 17, p. 423-441. doi: 10.1007/s10668-014-9552-7.

Collins, A.G., 1975, Geochemistry of oilfield waters: Development in Petroleum Science: Amsterdam, Elsevier, 495 p.

Colten-Bradley, V.A., 1987, Role of pressure in smectite dehydration-effects on geopressure and smectite-to-illite transformation: AAPG Bulletin, v. 71, p. 1414-1427.

Davies, R., and Stewart, S., 2005, Emplacement of giant mud volcanoes in the South Caspian Basin: 3D seismic reflection imaging of their root zones: Journal of Geological Society of London, v. 162, p. 1-4. doi: 10.1144/0016-764904-082.

Delisle, G., von Rad, U., Andruleit, H., von Daniels, C.H., Tabrez, A.R., and Inam, A., 2002, Active mud volcanoes on-and offshore eastern Makran, Pakistan: The International Journal of Earth Sciences, v. 91, p.93-110. doi: 10.1007/s005310100203.

Deville, E., Battani, A., Griboulard, R., Guerlais, S., Herbin, J.P., Houzay, J.P., Muller, C., and Prinzhofer, A., 2003, The origin and processes of mud volcanism: New insights from Trinidad, in Van Rensbergen, P., Hillis, R.R., Maltman, A.J., and Morley, C.K., eds., Subsurface sediment mobilization: Geological Society of London, Special Publications, London, The Geological Society, v. 216, p. 475-490. doi:10.1144/GSL.SP.2003.216.01.31.

Devlin, W., Cogswell, J., Gaskins, G., Isaksen, G., Pitcher, D., Puls, D., Stanley, K., and Wall, G., 1999, South Caspian basin: Young Cool and Full of Promise: GSA Today, v. 9, p. 1-9.

Dia, A.N., Castrec-Rouelle, M., Boul'egue, J., and Comeau, P., 1999, Trinidad mud volcanoes: Where do the expelled fluids come from?: Geochimica et cosmochimica ACTA, v. 63, p.1023-1038. doi: 10.1016/S0016-7037(98)00309-3.

Dimitrov, L.I., 2002, Mud volcanoes: The most important pathway for degassing deeply buried sediments: Earth Science Reviews, v. 59, p. 49-76. doi: 10.1016/S0012-8252(02)00069-7.

Dresel, P.E., and Rose, A.W., 2010, Chemistry and origin of oil and gas well brines in western Pennsylvania: Pennsylvania Geological Survey, 4th series, Open-File Oil and Gas Report 10-01.0, $48 \mathrm{p}$.

Etiope, G., Caracausi, A., Favara, R., Italiano, F., and Baciu, C., 2002, Methane emission from the mud volcanoes of Sicily (Italy): Geophysical Research Letters, v. 29, p. 14340-14343. doi: 10.1029/2001GL014340.

Etiope, G., Feyzullayev, A., and Baciu, C., 2009a, Terrestrial methane seeps and mud volcanoes: A global perspective of gas origin: Marine and Petroleum Geology, v. 26, p. 333-344. doi: 10.1016/j.marpetgeo.2008.03.001.

Etiope, G., Feyzullayev, A., Milkov, A.V., Waseda, A., Mizobe, K., and Sun, C.H., 2009b, Evidence of subsurface anaerobic biodegradation of hydrocarbons and potential secondary methanogenesis in terrestrial mud volcanoes: Marine and Petroleum Geology, v. 26, p.1692-1703. doi: 10.1016/j.marpetgeo.2008.12.002.

Etiope, G., Lassey, K.R., Klusman, R.W., and Boschi, E., 2008, Reappraisal of the fossil methane budget and related emission from geologic sources: Geophysical Research Letters, v. 35, L09307. doi: 10.1029/2008GL033623.

Etiope, G., Martinelli, G., Caracausi, A., and Italiano, F., 2007, Methane seeps and mud volcanoes in Italy: Gas origin, fractionation and emission to the atmosphere: Geophysical Research Letters, v. 34, L14303. doi: 10.1029/2007GL030341.

Etiope, G., Papatheodorou, G., Christodoulou, D., Ferentinos, G., Sokos, E., and Favali, P., 2006, Methane and hydrogen sulfide seepage in the NW Peloponnesus petroliferous basin (Greece): Origin and geohazard: AAPG Bulletin, v. 90 (5), p. 701-713. doi: 10.1306/11170505089.

Evans, W.C., White, L.D., and Rap, P., 1998, Geochemistry of some gases in hydrothermal fluids from the southern Juan de Fuca ridge: Journal of Geophysical Research, v. 15, p. 305-313. doi: 10.1029/JB093iB12p15305.

Feyzullayev, A., and Movsumova, U., 2001, About the origin of isotopically heavy $\mathrm{CO}_{2}$ in gases of Azerbaijan mud volcanoes: Azerbaijan Geology, v. 6, p. 96-105 (in Russian).

Feyzullayev, A.A., Guliyev, I.S., and Tagiyev, M.F., 2001, Source potential of the Mesozoic-Cenozoic rocks in the South Caspian Basin and their role in forming the oil 
accumulations in the Lower Pliocene reservoirs: Petroleum Geoscience, v. 7, p. 409-417. doi: 10.1144/petgeo.7.4.409.

Fitts, T.G., and Brown, K., 1999, Stress induced smectite dehydration ramifications for patterns of freshening fluid expulsion in the N. Barbados Accretionary Wedge: Earth and Planetary Science Letters, v. 172, p.179-197. doi: 10.1016/ s0012-821x(99)00168-5.

Fontes, J.C., and Matray, J.M., 1993, Geochemistry and origin of formation brines from the Paris Basin, France: 1. Brines Associated with Triassic Salts: Chemical Geology, v. 109, p.149-175. doi: 10.1016/0009-2541(93)90068-T.

Fowler, S.R., Mildenhall, J., Zalova, S., Riley, G., Elsley, G., Desplanques, A., and Guliyev, F., 2000, Mud volcanoes and structural development on Shah Deniz: Journal of Petroleum Science and Engineering, v. 28, p.189-206. doi: 10.1016/ S0920-4105(00)00078-4.

Friedman, G.M., Sanders, J.E., and Kopaska-Merkel, D.C., 1992, Principles of sedimentary deposits: Stratigraphy and sedimentology: New York, Macmillan Publishing Company, p. 717.

Gieskes, J.M., Blanc, G., Vrolijk, P., Elderfield, H., and Barnes, R., 1989, Hydrogeochemistry in the Barbados accretionary complex, Leg 110 ODP: Palaeogeography, Palaeoclimatology, Palaeoecology, v. 71, p. 83-96. doi: 10.1016/0031-0182(89)90031-X.

Giggenbach, W.F., 1992, Isotopic shifts in waters from geothermal and volcanic systems along convergent plate boundaries and their origin: Earth and Planetary Science Letters, v. 113, p. 495-510. doi: 10.1016/0012-821X(92)90127-H.

Giggenbach, W.F., 1997, The origin and evaluation of fluids in magmatic-hydrothermal systems, in Barnes, H.L., Wiley, J., and Sons, N.Y. eds. Geochemistry of hydrothermal ore deposits, 3rd edition: New York, John Wiley \& Sons, p. 737796.

Green, T., Abdullayev, N., Hossack, J., Riley, G., and Roberts, A.M., 2009, Sedimentation and subsidence in the South Caspian Basin, Azerbaijan: Geological Society, London, Special Publications, v. 312, 241-260. doi: 10.1144/SP312.12.

Guliyev, I.S., and Feizullayev, A.A., 1996, Geochemistry of hydrocarbon seepages in Azerbaijan, in Schumacher, D., and Abrams, M.A., eds., Hydrocarbon migration and its nearsurface expression, Volume 66: AAPG Memoir, The American Association of Petroleum Geologists, Tulsa, Oklahoma, p. 63-70. doi: 10.1306/M66606C5.

Guliyev, I.S., Huseynov, D., and Feizullaev, A., 2004, Fluids of mud volcanoes in the southern caspian sedimentary basin: Geochemistry and sources in light of new data on the carbon, Hydrogen and Oxygen Isotopic Compositions: Geochemistry International, vol. 42, p .688-695.

Haese, R., Ch., H., and de Lange, G.J., 2006, Pore water geochemistry of eastern Mediterranean mud volcanoes: Implication for fluid transport and fluid origin: Marine Geology, v. 225 (1), p. 191-208. doi: 10.1016/j.margeo.2005.09.001.

Hanor, J.S., 1994, Origin of saline fluids in sedimentary basins, in Parnell, J., ed., Geofluids: Origin, migration and evolution of fluids in sedimentary basins, Volume 78: Geological Society, Special Publication, London, The Geological Society, p. 151-174. doi: 10.1144/GSL. SP.1994.078.01.13.

Head, I.M., Jones, D.M., and Larter, S.R., 2003, Biological activity in the deep subsurface and the origin of heavy oil: Nature, v. 426 (6964), p. 344-352. doi: 10.1038/nature02134.
Hem, J.D., 1970, Study and interpretation of the chemical characteristics of natural water. USA Geological Survey, Water Supply Paper 1473.

Henderson, P., 1982, Inorganic Geochemistry: New York, Pergamon Press.

Hensen, C., Wallmann, K., Schmidt, M., Ranero, C.R., and Suess, E., 2004, Fluid expulsion related to mud extrusion off Costa Rica-a window to the subducting slab: Geology, v. 32, p.201-204. doi: 10.1130/G20119.1.

Hinrichs, K.U., Hayes, J.M., Bach, W., Spivack, A.J., Hmelo, L.R., Holm, N.G., Johnson, C.G., and Sylva, S.P., 2006, Biological formation of ethane and propane in the deep marine subsurface: Proceedings of the National Academy of Sciences, v. 103 (40), p. 14684-14689. doi: 10.1073/pnas.0606535103.

Horbe, A.M.C., 2011, Oxygen and hydrogen isotopes in pedogenic minerals - Implications for paleoclimate evolution in Amazonia during the Cenozoic: Geoderma, v. 16, p. 178-184. doi: 10.1016/j.geoderma.2011.03.017.

Hudson, S.M., Johnson, C.L., Efendiyeva, M.A., Rowe, H.D., Feyzullayev, A.A., and Aliyev, C.S., 2008, Stratigraphy and geochemical characterization of the Oligocene-Miocene Maikop series: Implications for the paleogeography of Eastern Azerbaijan: Tectonophysics, v. 451, p.40-55. doi: 10.1016/j.tecto.2007.11.045.

Hunt, J.M., 1984, Generation and migration of light hydrocarbons: Science, v. 226, p.1265-1270. doi: 10.1126/ science.226.4680.1265

Inan, S., Namik Yalcin, M., Guliev, I.S., Kuliev, K., and Feizullayev, A.A., 1997, Deep petroleum occurrences in the Lower Kura Depression, South Caspian Basin, Azerbaijan: An organic geochemical and basin modeling study: Marine and Petroleum Geology, v. 14, p. 731-762. doi: 10.1016/S02648172(97)00058-5.

Jakubov, A.A., Ali-Zade, A.A., and Zeinalov, M.M., 1971, Mud Volcanoes of the Azerbaijan SSR: Baku, Atlas (in Russian), Azerbaijan Academy of Sciences.

James, A.T., and Baker, D.R., 1976, Oxygen isotope exchange between illite and water at $22^{\circ} \mathrm{C}$ : Geochimica et cosmochimica ACTA, v. 40, p. 235-239. doi: 10.1016/0016-7037(76)90180-0.

James, R.H., Allen, D.E., and Seyfried, W.E., 2003, An experimental study of alteration of oceanic crust and terrigenous sediments at moderate temperatures $\left(51\right.$ to $\left.350{ }^{\circ} \mathrm{C}\right)$ : Insights as to chemical processes in near-shore ridge-flank hydrothermal systems: Geochimica et cosmochimica ACTA, v. 67, p. 681-691. doi: 10.1016/S0016-7037(02)01113-4.

James, R.H., and Palmer, M.R., 2000, Marine geochemical cycles of the alkali elements and boron: The role of sediments: Geochimica et cosmochimica ACTA, v. 64, p. 3111-3122. doi: 10.1016/S0016-7037(00)00418-X.

Jones, D.M., Head, I.M., Gray, N.D., Adams, J.J., Rowan, A.K., Aitken, C.M., Bennett, B., Huang, H., Brown, A., Bowler, B.F., Oldenburg, T., Erdmann, E., and Larter, S.R., 2008, Crude oil biodegradation via methanogenesis in subsurface petroleum reservoirs: Nature, v. 451 (7175), p.176-180. doi: 10.1038/ nature06484.

Katz, B., Narimanov, A., and Huseinzadeh, R., 2002, Significance of microbial processes in gases of the South Caspian basin: Marine and Petroleum Geology, v. 19, p.783-796. doi: 10.1016/S0264-8172(02)00086-7.

Khajeh, M., Rahmati, M., and Esmaili, N.A., 2007, lodine exploration in brines from Apsheron, Akchagyl and Cheleken formations at northern Gorgan, The 25th symposium of 
Geoscience, Geological Survey of Iran, Tehran (in Persian). doi: 10.1094/PDIS-91-4-0467B.

Kharaka, Y.K., and Mariner, R.H., 1989, Chemical geothermomethers and their application to formation waters from sedimentary basins, in Nancy, N., McCulloh, D., and Thane, H., eds., Thermal history of sedimentary basins, methods and case histories: New York, Springer, p. 99-117. doi: 10.1007/978-1-4612-3492-0_6.

Kharaka, Y.K., and Hanor, J.S., 2004, Deep fluids in the continents: I. sedimentary basins, in Drever, J.I., Holland, H.D., and Turekian, K.K., eds. exec., Treatise on Geochemistry, Volume 5: The Netherlands, Elsevier, p. 499-540. doi: 10.1016/B0-08043751-6/05085-4.

Kharaka, Y.K., and Smalley, W.C., 1976, Flow of water and solutes through compacted clays: AAPG Bulletin, v. 60, p. 973-980.

Knauth, L.P., 1988, Origin and mixing history of brines, Palo Duro Basin, Texas, USA: Applied Geochemistry, v. 3, p. 455-474. doi: 10.1016/0883-2927(88)90019-4.

Kopf, A., 2002, Significance of mud volcanism:Reviews of Geophysics, v. 40 (2), 1005. . doi: 10.1029/2000RG000093.

Kopf, A., and Deyhle, A., 2002, Back to the roots: Boron geochemistry of mud volcanoes and its implications for mobilization depth and global B cycling: Chemical Geology, v. 192, p. 195-210. doi: 10.1016/S0009-2541(02)00221-8.

Kopf, A., Klaeschen, D., and Mascle, J., 2001, Extreme efficiency of mud volcanism in dewatering accretionary prisms: Earth and Planetary Science Letters, v. 189, p.295-313. doi: 10.1016/S0012-821X(01)00278-3.

Kordjazi, M., Majidi, O., Mola Arazi, A.J., and Bagheri, S., 2014, Modeling and zonation of temperature by elevation in Golestan province, The 16th Geophysics Conference of Iran, Tehran, p. 244-250. (in Persian).

Lagunova, I.A., 1976, Origin of boron in waters of mud volcanoes: International Geology Review, v. 18, p.929-934. doi: 10.1080/00206817609471300.

Lavrushin, V.Y., Dubinina, E.O., and Avdeenko, A.S., 2005, Isotopic composition of oxygen and hydrogen in mud volcanic waters from Taman (Russia) and Kakhetia (Eastern Georgia): Lithology and Mineral Resources, v. 2, p. 123-137. doi: 10.1007/s10987-005-0014-z.

Lavrushin, V.Y., Guliev, I.S., Kikvadze, O.E., Ad.A., A., Pokrovsky, B.G., and Polyak, B.G., 2015, Waters from mud volcanoes of Azerbaijan: Isotopic-geochemical properties and generation environments: Lithology and Mineral Resources, v. 50, p. 1-25. doi: 10.1134/S0024490215010034.

Lüders, V., Plessen, B., Romer, R.L., Weise, S.M., Banks, D.A., Hoth, P., Dulski, P., and Schettler, G., 2010, Chemistry and isotopic composition of Rotliegend and Upper Carboniferous formation waters from the North German Basin: Chemical Geology, v. 276, p. 198-208. doi: 10.1016/j.chemgeo.2010.06.006.

Mazzini, A., Svensen, H., Planke, S., Guliyev, I., Akhmanov, G.G., Fallik, T., and Banks, D., 2009, When mud volcanoes sleep: Insight from seep geochemistry at the Dashgil mud volcano, Azerbaijan: Marine and Petroleum Geology, v. 26, p.1704-1715. doi: 10.1016/j.marpetgeo.2008.11.003.

Mehrabi, B., Mazzini, A., Farhadian Babadi, M., Poludetkina, E., and Inguaggiato, S., 2017, Origin of hydrocarbon gas in southeast of Caspian Sea (Gorgan plain) mud volcanoes based on molecular and isotopic composition of carbon and hydrogen: Journal of Earth Science Research, v. 29, p. 87-102 (in Persian).
Milkov, A.V., 2000, Worldwide distribution of submarine mud volcanoes and associated gas hydrates: Marine Geology, v. 167, p. 29-42. doi: 10.1016/S0025-3227(00)00022-0.

Milkov, A.V., 2005, Global distribution of mud volcanoes and their significance in petroleum exploration, as a source of methane in the atmosphere and hydrosphere and as geohazard, in Martinelli, G., and Panahi, B. eds., Mud volcanoes: Geodynamics and seismicity, Nato Science Series IV: Earthquake Engineering, Volume 51: The Netherlands, Springer, p. 29-34.

Milkov, A.V., 2011, Worldwide distribution and significant of secondary microbial methane formed during petroleum biodegradation in conventional reservoirs: Organic Geochemistry, v. 42, p. 184-207. doi: 10.1016/j.orggeochem.2010.12.003.

Milkov, A.V., 2018, Secondary microbial gas, in Wilkes, H., ed., Hydrocarbon, oils and lipids: Diversity, origin, chemistry and fate, handbook of hydrocarbon and lipid microbiology: Cham, Springer, p. 1-10.

Milkov, A.V., and Etiope, G., 2018, Revised genetic diagrams for natural gases based on global dataset of $>20,000$ samples: Organic Geochemistry, v. 125, p. 109-120. doi: 10.1016/j. orggeochem.2018.09.002.

Mosavi Rohbakhsh, M., 2001, The geology of Caspian Sea, 1st edition: Geological Survey and Mineral Exploration of Iran, Tehran, p. 260.

Omrani, H., and Raghimi, M., 2018, Origin of the mud volcanoes in the south east Caspian Basin, Iran: Marine and Petroleum Geology, v. 96, p.615-626. doi: 10.1016/j. marpetgeo.2018.05.017.

Oppo, D., Capozzi, R., Nigarov, A., and Esenov, P., 2014, Mud volcanism and fluid geochemistry in the Cheleken peninsula, western Turkmenistan: Marine and Petroleum Geology, v. 57, p. 122-134. doi: 10.1016/j.marpetgeo.2014.05.009.

Pallasser, R.J., 2000, Recognising biodegradation in gas/oil accumulations through the $\delta^{13} \mathrm{C}$ compositions of gas components: Organic Geochemistry, v. 31, p. 1363-1373. doi: 10.1016/s0146-6380(00)00101-7.

Pinti, D.L., Be'land-Otis, C., Tremblay, A., Castro, M.C., Hall, C.M., Marcil, J.S., Jean-Yves Lavoie, J.Y., and Lapointe, R., 2011, Fossil brines preserved in the St-Lawrence Lowlands, Que'bec, Canada as revealed by their chemistry and noble gas isotopes: Geochimica et cosmochimica ACTA, v. 75, p. 4228-4243. doi: 10.1016/j.gca.2011.05.006.

Planke, S., Svensen, H., Hovland, M., Banks, D.A., and Jamtveit, B., 2003, Mud and fluid migration in active mud volcanoes in Azerbaijan: Geo-Marine Letters, v. 23, p.258-268. doi: 10.1007/s00367-003-0152-z.

Prinzhofer, A., and Deville, E., 2013, Origins of hydrocarbon gas seeping out from offshore mud volcanoes in the Nile delta: Tectonophysics, v. 591, p.52-61. doi: 10.1016/j. tecto.2011.06.028

Raisossadat, S.N., 2004, The ammonite family deshayesitidae in the Kopet Dagh basin, north-east Iran: Cretaceous Research, v. 25, p. 115-136. doi: 10.1016/j.cretres.2003.10.007.

Ray, J.S., Kumar, A., Sudheer, A.K., Deshpande, R.D., Rao, D.K., Patil, D.J., Awasthi, N., Bhutani, R., Bhushan, R., and Dayal, A.M., 2013, Origin of gases and water in mud volcanoes of Andaman accretionary prism: Implications for fluid migration in forearcs: Chemical Geology, v. 347, p.102-113. doi: 10.1016/j.chemgeo.2013.03.015.

Rezvandehy, M., Aghababaei, H., and Tabatabaee Raissi, S.H., 2011, Integrating seismic attributes in the accurate 
modeling of geological structures and determining the storage of the gas reservoir in Gorgan Plain (North of Iran): Jurnal of Applied Geophysics, v. 73, p.187-195. doi: 10.1016/j.jappgeo.2010.12.008.

Rittenhouse, G., 1967, Bromine in oil-field waters and its use in determining possibilities of origin of these waters: AAPG Bulletin, v. 51, p. 2430-2440.

Robert, A.M.M., Letouzey, J., Kavoosi, M.A., Sh., S., Müller, C., Vergés, J., and Aghababaei, A., 2014, Structural evolution of the Kopeh Dagh fold-and-thrust belt (NE Iran) and interactions with the South Caspian Sea Basin and Amu Darya Basin: Marine and Petroleum Geology, v. 57, p. 68-87. doi: 10.1016/j.marpetgeo.2014.05.002.

Saeedi, A., and Andalibi, M.J., 1993, The geology map of Gonbad-e-Kaous: Geological Survey and Mineral Exploration of Iran, scale 1:250 000, 1 sheet.

Schoell, M., 1980, The hydrogen and carbon isotopic composition of methane from natural gases of various origins: Geochimica et cosmochimica ACTA, v. 44, p. 649-666. doi: 10.1016/0016-7037(80)90155-6.

Schoell, M., 1983, Genetic characterization of natural gases: AAPG Bulletin, v. 67, p. 2225-2238.

Schwarcz, H.P., Agyei, E.K., and McMullen, C.C., 1969, Boron isotopic fractionation during clay adsorption from sea-water: Earth and Planetary Science Letters, v. 6, p. 1-5. doi: 10.1016/0012-821X(69)90084-3.

Seewald, J.S., 2003, Organic-inorganic interactions in petroleum producing sedimentary basins: Nature, v. 426, p. 327-333. doi: 10.1038/nature02132.

Seewald, J.S., Benitez-Nelson, B.C., and Whelan, J.K., 1998, Laboratory and theoretical constraints on the generation and composition of natural gas: Geochimica et cosmochimica ACTA, v. 62, p. 1599-1617. doi: 10.1016/S00167037(98)00000-3.

Shamsi, A., and Kazemi, G.A., 2014, A review of research dealing with isotope hydrology in Iran and the first Iranian meteoric water line: Geopersia, v. 4 (1), p. 73-86.

Sharafi, M., ashuri, M., Mahboubi, A., and Moussavi Harami, S.R., 2012, Stratigraphic application of Thalassinoides ichnofabric in delineating sequence stratigraphic surfaces (Mid-Cretaceous), Kopet-Dagh Basin, northeastern Iran: Palaeoworld, v. 21 (3), p. 202-216. doi: 10.1016/j.palwor.2012.06.001.

Skelton, A., Löwhagen, L., Fairchild, I.J., Boyce, A., Mörth, C.M., Siegmund, H., Webster, D., and Spencer, A.M., 2019, Stable isotopes of oxygen and hydrogen in meteoric water during the Cryogenian Period: Precambrian Research, v. 320, p. 253-260. doi: 10.1016/j.precamres.2018.11.006.

Smith-Rouch, L.S., 2006, Oligocene-Miocene Maykop/Diatom Total Petroleum System of the South Caspian Basin Province, Azerbaijan, Iran, and Turkmenistan: U.S. Geological Survey Bulletin 2201-I, U.S. Geological Survey, Reston, Virginia, $27 \mathrm{p}$.

Spivack, A.J., Palmer, M.R., and Edmond, J.M., 1987, The sedimentary cycle of the boron isotopes: Geochimica et cosmochimica ACTA, v. 51, p.1939-1949. doi: 10.1016/00167037(87)90183-9.

Stewart, S.A., and Davies, R.J., 2006, Structure and emplacement of mud volcano systems in the South Caspian Basin: AAPG Bulletin 90, 771-786. doi: 10.1306/11220505045.

Tagiyev, M.F., Nadirov, R.S., and Bagirov, E.B., 1997, Geohistory, thermal history and hydrocarbon generation history of the north-west South Caspian Basin: Marine and Petroleum
Geology, v. 14, p. 363-382. doi: 10.1016/S0264-8172(96) 00053-0.

Takai, K., Nakamura, K., Toki, T., Tsunogai, U., Miyazaki, M., Miyazaki, J., Hirayama, H., Nakagawa, S., Nunoura, T., and Horikosh, K.,, 2008, Cell proliferation at 122 degrees $C$ and isotopically heavy $\mathrm{CH}_{4}$ production by a hyperthermophilic methanogen under high-pressure cultivation: Proceedings of the National Academy of Sciences of USA, v. 105, p.10949-10954. doi: 10.1073/pnas.0712334105.

Tassi, F., Bonini, M., Montegrossi, G., Capecchiacci, F., Capaccioni, B., and Vaselli, O., 2012, Origin of light hydrocarbons in gases from mud volcanoes and $\mathrm{CH}_{4}$-rich emissions: Chemical Geology, v. 294-295, p.113-126. doi: 10.1016/j.chemgeo.2011.12.004.

Teichert, B.M.A., Torres, M.E., Bohrmann, G., and Eisenhauer, A., 2005, Fluid sources, fluid pathways and diagenetic reactions across an accretionary prism revealed by $\mathrm{Sr}$ and $\mathrm{B}$ geochemistry: Earth and Planetary Science Letters, v. 239 (1-2), p. 106-121. doi: 10.1016/j.epsl.2005.08.002.

Torres, M.A., 2007, The petroleum geology of Western Turkmenistan: The Gograndage Okarem province, in Yilmaz, P.O., and Isaksen, G.H., eds., Oil and gas of the Greater Caspian area, American Association of Petroleum Geologists, Studies in Geology, Volume 55, The American Association of Petroleum Geologists, Tulsa, Oklahoma, pp. 109-132.

Vaselli, O., Tassi, F., Montegrossi, G., Capaccioni, B., and Giannini, L., 2006, Sampling and analysis of volcanic gases: ACTA Volcanology, v. 18, p. 65-76.

White, D.E., 1965, Saline waters of sedimentary rocks, in Young, A., and Galley, G.E. eds., Fluid in Subsurface Environments, AAPG Memoir, v. 4, p. 342-366. doi: 10.1306/ M4360C14.

Whiticar, M.J., 1994, Correlation of natural gases with their sources, in Magoon, L.B, and Dow, W.G., eds., The Petroleum System: from Sources to Trap, AAPG Memoir, v. 60, p. 261-283. doi: 10.1306/M60585C16.

Whiticar, M.J., 1999, Carbon and hydrogen isotope systematics of bacterial formation and oxidation of methane: Chemical Geology, v. 161, p. 291-314. doi: 10.1016/S0009-2541(99) 00092-3.

Williams, L.B., Hervig, R.L., Holloway, J.R., and Hutcheon, I., 2001, Boron isotope geochemistry during diagenesis, part I. Experimental Determination of Fractionation during Illitization of Smectite: Geochimica Et Cosmochimica ACTA, v. 65, p.1769-1782. doi: 10.1016/s0016-7037(01)00557-9.

Worden, R.H., 1996, Controls on halogen concentrations in sedimentary formation waters: Mineralogical Magazine, v. 60, p.259-274. doi: 10.1180/minmag.1996.060.399.02.

You, C.F., Castillo, P.R., Gieskes, J.M., Chan, L.H., and Spivack, A. J., 1996, Trace element behavior in hydrothermal experiments: Implications for fluid processes at shallow depths in subduction zones: Earth and Planetary Science Letters, v. 140, p. 41-52. doi: 10.1016/0012-821X(96)00049-0.

You, C.F., Gieskesb, J.M., Leec, T., Yuic, T.F., and Chenc, H.W., 2004, Geochemistry of mud volcano fluids in the Taiwan accretionary prism: Applied Geochemistry, v. 19, p. 695-707. doi: 10.1016/j.apgeochem.2003.10.004.

You, C.F., Spivack, A.J., Smith, J.H., and Gieskes, J.M., 1993, Mobilization of boron in convergent margins: Implications for the boron geochemical cycle: Geology, v. 21, p. 207-221. doi:10.1130/0091-7613(1993)021<0207:MOBICM>2.3.CO;2. 